\title{
Demographic dynamics of poverty and income inequality: the case of Brazil
}

\author{
Jeronimo Oliveira Muniz*
}

\begin{abstract}
There is a common belief that higher reproduction rates among the poor will increase average poverty levels, drive inequality up, prevent economic development and reduce upward mobility. To test this hypothesis we used 1980, 1991 and 2000 Brazilian Census data. We first present rates of demographic growth among subpopulations with different levels of income (poor, middle and rich classes) and then 1) evaluate the impact of differential demographic rates on the size, composition and growth of income classes and on the distribution of income through population projections, and 2) conduct stable population analysis, demonstrating the long-term implications of maintaining or changing current demographic patterns to the composition of poverty and inequality.
\end{abstract}

Keywords: Poverty. Inequality. Brazil. Mortality. Fertility. Reproduction rates.

\section{Background and significance}

Previous literature has sought to understand how differences in reproductive rates impact population growth and the distribution of traits in the long-run (PRESTON; CAMPBELL, 1993). In a seminal paper published in 1986, David Lam called attention to the impact that differential demographic rates and population composition could have on the distribution of income. Using Brazil as an empirical example, he concluded that differential fertility and mobility have distinct effects on income distribution depending on which inequality measure is used (i.e. coefficient of variation or log variance of income). Lam's article sheds light on the "ambiguous" effects of differential fertility and population composition on inequality measures, and subsequent studies have demonstrated the same (CHU; JIANG, 1997; COWELL;
JENKINS, 1995; DE LA CROIX; DOEPKE, 2003; JENKINS, 1995; SHORROCKS; WAN, 2005).

These articles suggest that in order to understand how inequality is created and maintained over time, one must address the relationship between income distribution and the reproductive behavior of particular income groups. One must examine the process by which a socioeconomically differentiated population reproduces itself (CHU; KOO, 1990; MARE, 1997). This is important for two reasons.

First, because it has been argued that income inequalities in developing countries are caused by high population growth and that high population growth rates in most developing areas are due to the high reproductive rate of the poor (BROCKERHOFF; BRENNAN, 1998; CHU; KOO, 1990, p.1135; KREMER; CHEN, 2002,

\footnotetext{
${ }^{*}$ Ph.D. in Sociology/Demography by the University of Wisconsin, Madison, assistant professor of Sociology at the Federal University of Minas Gerais.
} 
p.228). For the same reproductive level, individuals will receive a smaller share of resources when income is low than when it is high. Inequality results from this differential allocation of income, in which many people get few and few people get many. As a corollary, as class specific reproductive rates converge, inequality should decline.

Second, analyzing how different socioeconomic groups reproduce over time indicates their potential for future growth and elucidates how individual income classes combine to generate inequality in the total population. This type of analysis is relevant to evaluate the impact that distinct mortality and fertility regimes may have on the composition of poverty and income inequality. Although it is not surprising that the poor have higher birth rates than the middle and rich classes, this pattern does not necessarily imply in greater rates of growth since the poor are also subject to higher mortality rates. Thus, it is important to account for fertility and mortality rates corresponding to different levels of income in order to determine population growth.

Two studies investigated the relationship between class reproduction, poverty and inequality using empirical evidence from Brazil. Wood and Carvalho (1988) and Camarano and Beltrão (1995) estimated fertility, mortality, natural and intrinsic growth rates by household income in Brazil between 1960 and 1980. The present investigation uses the studies mentioned as a point of reference to build knowledge, but it differs from them in three aspects. First, it provides recent estimates of age and income-specific fertility and mortality rates for Brazil in the past three censuses. Second, it offers side by side comparisons of mortality and fertility rates by income using alternative demographic methods that use the same data source. In particular, it estimates fertility using two different methods: Brass indirect method of fertility (e.g. P/F method) and the own children method (CHO; RETHERFORD; CHOE, 1986) for estimating age-specific fertility rates. Mortality is estimated by combining three indirect techniques: Brass indirect method of childhood mortality (BRASS et al. 1968), a variation of his method to adult mortality (HILL; TRUSSELL, 1977), and the Brass (1971) relational model based upon a logit transformation of Brazilian standard life tables. Third, it asks how much poverty and inequality would Brazil have had if the demographic conditions observed in past censuses had remained the same. In answering this counterfactual question, it demonstrates the role of demographic growth to the generation of poverty and income inequality. This article advances our understanding of the reproduction of inequality by providing current estimates of Brazilian reproductive rates from 1980 to 2000 , by offering comparative estimates that rely on alternative and robust indirect demographic methods, and by isolating the effect of class-specific demographic rates on poverty and income inequality.

\section{Data and methods}

The variables required for the analysis were: age, sex, children ever born, children surviving, year and month of the most recent birth, orphan hood status and family income per person. The working dataset includes special tabulations of these variables for the 1980, 1991 and 2000 Brazilian Censuses produced by the Instituto Brasileiro de Geografia e Estatística (IBGE). Brazilian censuses are publicly available at the IPUMS International website (RUGGLES et al., 2004). Unlike the vital registration system, census data contain a wide range of information about individuals such as

\footnotetext{
${ }^{1}$ We use per head family income, which takes into account all the sources of income within the family, the number of people and the role of the family as a solidary unit of consumption and earnings (ROCHA, 2000). Family per head income "corrects" for family size as the total income is shared equally among all the family members (DATTA; MEERMAN, 1980). A similar measure, per head household income, has also been utilized in other studies of inequality (FERREIRA; BARROS, 1999; FIORIO, 2006; FIRPO; GONZAGA; NARITA, 2003; PERO; SZERMAN, 2005) and provides similar results. Gross monthly family income per head is measured in January 2002 Brazilian Reais. The Brazilian INPC and IGP official consumer price index are used to convert current incomes into real ones (CORSEUIL; FOGUEL, 2002).
} 
their income, educational attainment, family organization and composition, place of residence, number of children ever born and number of children who were alive at the date of the census. Individual-level data can thus be utilized to generate demographic rates, specific to different socioeconomic groups of the population (WOOD; CARVALHO, 1988, p. 9).

Mortality and fertility rates are estimated for three groups: poor, middle and rich classes. The poor class corresponds to 33 per cent of the population in the bottom of the income ${ }^{1}$ distribution of 1980 ; the one per cent of the population at the top of the income distribution represents the richest; and the middle class is the remaining population in between. The poverty line is thus defined by the value separating 33 per cent of the population with lowest per head family income. ${ }^{2}$ This value is low enough to avoid any controversies about who is poor and is compatible with the popular perception of what represents an "insufficient" income to survive. Using data from the Northeast and Southeast regions of Brazil, Medeiros (2005, p. 120) reported that 83 per cent of the population considers the estimated poverty line of $R \$ 80.42$ per head $^{3}$ as "insufficient to cover the living expenses $(85 \%)$ and to purchase food (49\%) for the family.

In summary, because of its methodological simplicity, the three income classes are defined as:

- Poor class: 33 per cent of the population at the bottom of the family per head income distribution in 1980. The value of $R \$ 80.42$ is the upper limit of the poor class in 1980, 1991 and 2000;

- Middle class: population between the $33^{\text {rd }}$ and $99^{\text {th }}$ percentiles of the income distribution;

- Rich class: one per cent of the population at the top of the family per head income distribution. Individuals with per head family income higher than $\mathrm{R} \$ 2,374$ are considered rich. This criterion considers Medeiros's suggestion (2005) of applying a distributive rule to define a "richness line", above which the sum of incomes held by the richest 1 percent of the population is identical to the amount held by the poorest 33 percent. Hypothetically, if the sum of resources retained by those above the $99^{\text {th }}$ percentile were transferred to those below the 33th percentile of the income distribution, poverty could be eliminated.

The main function of imaginary lines defining the poor and the rich is to discriminate broad but relatively homogeneous social groups to allow the study of their characteristics rather than to generate a criterion to implement and execute distributive public policies of any kind. In the absence of official and consensual definitions for what "economic classes" mean, it seems reasonable to avoid a series of contestable presuppositions and to understand the definition of class as a simple instrument required for an analytical end. It is preferable to adopt a criterion that is at the same time easy to implement, relevant to the object of study and compatible with previous studies than to struggle with alternative class schemes whose validity is debatable and at best conditioned on the goal of analysis.

Our definition of "social/economic class" follows a sociological agreement according to which social classes should characterize homogeneous groups, be meaningful for analytical purposes and relatively comparable over time (GRUSKY; SORENSEN, 1998; HAUSER; WARREN, 1997; SORENSEN, 1991; WRIGHT, 1997; WRIGHT, 2005). Our definition of class

\footnotetext{
2 Official poverty lines do not exist in Brazil. Studies have not agreed on the best methodological procedures for measuring poverty (ROCHA, 2000; FERREIRA; LANJOUW; NERI, 2000; NERI, 2000). Some studies suggest that a poverty line should not even be implemented in Brazil because it would create an inflexible yardstick to implement compensatory policies (SCHWARTZMAN, 2002).

${ }^{3}$ This value was equal to $\$ 44.5$ per month in October 2007.
} 
fulfills these requirements and does not change over time. It does not change between 1980, 1991 and 2000. Once we define the poor as 33 per cent of the population at the bottom of the income distribution in 1980, we take the absolute value separating this same 33 per cent in 1980 to define the poor in 1991 and in 2000 as well. Example: In 1980, $\mathrm{R} \$ 80.42$ (about $\$ 44.5$ ) defines the poverty line. In 1991 and in $2000, R \$ 80.42$ per head is the same value utilized to define the poverty threshold. As a result, the size of the population in the poor class changes over time, but the definition of who is poor remains the same. The same logic follows for the rich and middle classes. Thus, the cutting points utilized to identify social classes do not change over time, but the share of population in each one of the "classes" does. This change is exactly what we want to analyze in order to infer demographic fluctuations in the size of the three classes. All income values are real, not current, and hence comparable over time.
After excluding missing and zero income values, the final distribution of individuals in each social class and year looks as follows ${ }^{4}$ :

Graph 1 shows that the proportion of individuals living below poverty was 31 per cent in 1980, increased to 37 per cent in 1991 and then declined to 26 per cent in 2000 . The rich population remained relatively stable, while the middle class declined to 62 per cent and then increased to 72 per cent in 2000.

\section{Estimating fertility rates}

Income-specific fertility rates are calculated using indirect methods developed by Brass et al (1968) and the "own-children method" of fertility developed by Cho et al (1986). The indirect method requires two types of information: (i) the number of children born in the past twelve months, which is a measure of current fertility, and (ii) the number of children ever born, or parity, which is retrospective information less subject to memory error. The current fertility

GRAPH 1

Population distribution by income class Brazil - 1980-2000

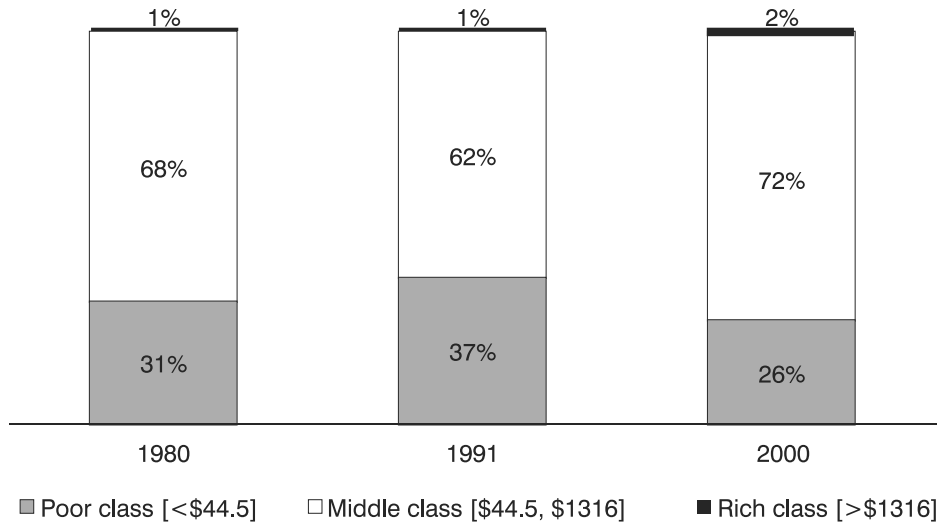

Source: Self-elaboration based on the 1980, 1991 and 2000 Brazilian Census.

\footnotetext{
${ }^{4}$ Missing and zero income values accounted for $3.5 \%$ of the total sample in $1980,3.35 \%$ in 1991 , and $6.54 \%$ in the 2000 Brazilian Census. These cases were excluded to avoid biases in the dispersion of income, which could compromise the measure of inequality. Excluding these cases assures sample consistency between the demographic and inequality measures.
} 
rates of women 15-49 years old provide the age pattern of childbearing. But because of the effects of reference period error - women may not respond with the correct time span in mind when asked about the children born in the past twelve months - an adjustment must be made by a factor equal to $P / F$, where $P$ is parity to women $20-29$ years old or the observed children ever born values, and $F$ is the sum of age-specific fertility rates for women of the same age. Given we expect births past year to be under reported, we expect "F" values to be lower than "P" values, so that the ratio $P / F$ will be greater than one. The $P / F$ ratio may be thought of as a correction factor that is applied to reported numbers of births in the past year, or to age-specific birth rates or total fertility rates calculated from these numbers of births, to estimate the corresponding true values ${ }^{5}$. The rates represent, therefore, the childbearing experience of women 20-29 years of age who had a given level of per head income on the census date.

The alternative to estimate incomespecific fertility rates is the own-children method. The advantage of this method is that it (i) provides detailed age-specific estimates by single years of age and any socioeconomic characteristic (i.e. income); (ii) only one census is required to generate estimates to even fifteen years prior to the census; (iii) the population does not have to be closed to migration, and (iv) the method is relatively insensitive to recall errors (FEENEY, 1975). The logic of the method consists in estimating the number of women (denominator) and births (numerator) by age and age of mother in each year, who were living in the same family and who had a mother-child tie. Agespecific fertility rates can then be estimated by the division of the number of births by the mean number of women at each single year of age for each year preceding the census (CHO et al., 1986). Miranda-Ribeiro (2007) applied the own-children method to estimate fertility rates in Brazil and its states in 1980,
1991 and 2000. She did not look at fertility differentials by income, but her results for the entire country are reassuring because they are similar to the ones reported in the present study.

After cross validating fertility estimates using these two methods, final estimates of class-specific fertility were obtained by averaging the rates in 1980, 1991 and 2000. Averaging the rates helps to dissolve any error of estimates caused by the violation of assumptions implicit in the techniques. Age specific fertility rates are estimated for intercensual periods (1985 and 1995) by linearly interpolating age-class-specific fertility rates between two census periods.

\section{Estimating mortality rates}

The estimation of income-specific life expectancies requires the calculation of life tables for each income category (poor, middle, rich). To retrieve these tables we combine estimates of infant and adult mortality using the logit relational system suggested by Brass (1971). The relational model consists in combining income specific mortality estimates by age with a previously defined general mortality standard describing the mortality experience of that population at every age. In this analysis we utilize Brazilian standards of mortality in combination with indirect estimates of adult and child mortality to retrieve five-year life tables for each income class.

Brass' method of indirect child mortality estimation is based on the number of children ever born and the number of children surviving by age of mother (BRASS et al., 1968). "The proportion of children surviving among children ever born to women aged 20-24, 25-29 and 30-34, when multiplied by the proper correction factors, yields estimates of the probability of death at exact ages 2, 3 and 5. These values correspond to the ${ }_{\mathrm{x}} \mathrm{q}_{0}$ life table function (in this case ${ }_{2} \mathrm{q}_{0},{ }_{3} \mathrm{q}_{0},{ }_{5} \mathrm{q}_{0}$ )" (WOOD; CARVALHO,

\footnotetext{
5 For a detailed presentation of the P/F ratio method see Manual X: Indirect Techniques for Demographic Estimation, Chapter II, Section B, pages 31-37, Population Studies No. 81, Department of International Economic and Social Affairs, United Nations, New York, 1983.
} 
1988, p. 263). Infant mortality estimates represent the first component towards the estimation of a full income specific life table.

The other component utilized to retrieve a full life table is an estimate of how mortality will look at older age cohorts. The logic of the method is similar to the one utilized in childhood mortality estimates but consists in converting non-orphaned proportions into conventional probabilities of surviving. The details of the method are provided by Hill and Trussell (1977) and summarized by Preston, Heuveline and Guillot (2001, p. 233-237).

Estimated values of child and adult mortality are representative indicators of mortality levels for different ages (i.e. different cohorts born in different years) and are associated with a full life table that can be obtained in combination with a predefined mortality pattern for both sexes. The selected mortality pattern reflects the mortality experience in the general Brazilian population, but the final specific mortality standard reflects the mortality experience of each income class since it is adjusted by estimated levels of child and adult mortality calculated through indirect methods. So even if the income specific mortality pattern departs from the Brazilian one, this would not invalidate the primary focus of analysis, which is on relative differences between income groups rather than on absolute levels of mortality. The combination of child and adult mortality estimates with the general Brazilian standards guarantees that differences in mortality levels will exist even when the standard employed to combine these estimates is the same.

The main caution on using mortality estimates by income classes is that survival probabilities can be distorted if mobility took place from one level of income to another. A woman may have been recorded as belonging to income class $(i+1)$ in 1990, but if she was upwardly mobile in the past ten years or so, the mortality of her children could correspond in reality to income level (i) (given the retrospective nature of the child mortality measure). This bias, however, is minimized with fewer income categories. The use of only three income categories (poor, middle and rich) decreases the susceptibility of mortality estimates to this mobility bias. More disaggregated estimates of mortality are more likely to be influenced by the mobility bias, and should be interpreted with this caveat in mind.

\section{Population projections by age and income class}

The projection of the poor, middle and rich classes utilizes the set of fertility and mortality rates estimated for these same classes. The projections are divided by five year age groups and income classes, but they are not separated by sex. They also assume that each income class is closed to international migration and to internal migration, that is, the mobility of individuals between classes is not taken into account in the projection models. Since the economic status of individuals is likely to change over their life cycle, we do not expect to obtain projections that are compatible with what is actually reported at the end of the projection period. The goal of this exercise is to show how a population would look "if only" fertility and mortality were influencing population dynamics. Projecting the size of income classes with only fertility and mortality rates is a valid exercise to inform and highlight the separate roles of social mobility and differential fertility and mortality in affecting future population growth. Therefore, only differential fertility and mortality rates are considered in the dynamics of growth and distribution of the poor, middle and rich classes. Comparing projected and reported populations will show how much social mobility influences the size of specific income classes.

We utilize the cohort component method to project income subgroups with specific fertility and mortality changes over time in each class. The parameters of the cohort component method are expressed in the compact Leslie matrix form (LESLIE, 1945). To illustrate how fertility and mortality of specific income classes can be expressed in the matrix form we provide an example for a single population and then we show how it can be adapted to combine the three subpopulations of interest. 
According to Rogers (1968), for a single population, the general model surviving an age distribution forward through time may be expressed by a summation of multiplication of matrices according to the equation below:

$$
\mathrm{w}^{\mathrm{t}+1}=\mathrm{Sw}^{\mathrm{t}}+\mathrm{Mw}^{\mathrm{t}}
$$

Where:

$$
\underset{\mathbf{n} \times \mathbf{n}}{\mathrm{S}}=\left[\begin{array}{ccccccc}
0 & b_{1} & b_{2} & \cdots & b_{u} & 0 & 0 \\
{ }_{11} d_{r+} & 0 & 0 & \cdots & \cdots & \cdots & 0 \\
0 & { }_{r+1} d_{r+2} & 0 & \cdots & \cdots & \cdots & 0 \\
0 & 0 & { }_{r+1} d_{r+2} & \cdots & \cdots & \cdots & 0 \\
\vdots & & & \ddots & & & 0 \\
\vdots & & & & \ddots & & \\
0 & & & & & & \\
& & & & \\
& d_{n-1} & 0
\end{array}\right],
$$

$$
\mathbf{W}^{\mathrm{t}}=\left[\begin{array}{c}
w_{r}^{t} \\
w_{r+1}^{t} \\
w_{r+2}^{t} \\
\vdots \\
\vdots \\
w_{n-1}^{t} \\
w_{n}^{t}
\end{array}\right] \mathbf{\mathrm { M } \times \mathbf { n }}=\left[\begin{array}{ccccc}
0 & 0 & \cdots & \cdots & 0 \\
m_{1} & 0 & & & 0 \\
0 & m_{2} & \ddots & & \vdots \\
\vdots & & & \ddots & \vdots \\
0 & \cdots & \cdots & m_{n-1} & 0
\end{array}\right]
$$

$w_{\mathrm{r}}^{\mathrm{t}}=$ population in the $r$ th age group at time t;

$b_{\mathrm{r}}=$ number of births surviving to the $\mathrm{t}+1$ in the $r$ th childbearing age group;

$d_{\mathrm{r}}=$ proportion of people who "survived" between ages $r$ and $r+1$ st between $\mathrm{t}$ and $\mathrm{t}+1$. $m_{\mathrm{i}}=$ net migration/mobility rate for the $i$ th age group.

Survivorship ratios are stored in the lower diagonal while the average fertility rate for each age group required to survive resulting births are expressed in the first row. Disaggregating the total population into three subpopulations, $\mathbf{w}^{\mathrm{t}}=\mathbf{w}_{\mathbf{1}}{ }^{\mathrm{t}}+\mathbf{w}_{\mathbf{2}}{ }^{\mathrm{t}}+\mathbf{w}_{\mathbf{3}}{ }^{\mathrm{t}}$ and assuming that there is no external migration and no population exchanges between the three subpopulations (e.g. $M=0$ ), we may express the fundamental model of population projection for a closed system with three groups as: $\left[\begin{array}{c}\mathrm{w}_{\text {POOR }}^{\mathrm{t}+5} * \\ \mathrm{w}_{\text {MIDDLE }}^{\mathrm{t}+5} \\ \mathrm{w}_{\text {RICH }}^{\mathrm{t}+5}\end{array}\right]=\left[\begin{array}{ccc}\mathrm{S}_{P O O R} & 0 & 0 \\ 0 & \mathrm{~S}_{\text {MIDDLE }} & 0 \\ 0 & 0 & \mathrm{~S}_{\text {RICH }}\end{array}\right] \times\left[\begin{array}{c}\mathrm{w}_{\text {POOR }}^{\mathrm{t}} \\ \mathrm{w}_{\text {MIDDLE }}^{\mathrm{t}} \\ \mathrm{w}_{\text {RICH }}^{\mathrm{t}}\end{array}\right]$

In this block matrix model, the poor, middle and rich subpopulations have their own set of fertility and mortality parameters, which are represented in Leslie matrices $\mathbf{S}$. The asterisk indicates that the population projected five years later does not take into account mobility. External migration and mobility (or interclass migrations) are not considered in this projection matrix. The population projection scheme illustrating population dynamics over time is represented by the multiregional Leslie matrix for three classes: poor, middle and rich.

\section{Results}

This section presents three sets of results. The first set describes class-specific fertility and mortality estimates for 1980, 1991 and 2000 using the methods suggested above. The second set introduces class specific net reproduction (NRR) and stable growth rates. The third set of results compares class specific projected and recorded populations between 1980 and 1990, and between 1990 and 2000 under realistic scenarios of decline in total fertility and mortality rates. Each class specific projection assumes that total fertility has linearly declined over the decade. We average class specific life tables of 1980 and 1991 for the projection between 1980 and 1990. Similarly, the projection between 1990 and 2000 assumes that mortality has remained constant and is represented by the average life table of 1990 and 2000.

\section{Age-specific fertility rates by year and income class}

Total fertility rates (TFR) are a useful measure because they remove the influence of differences in age structures between different populations.

Fertility estimates using Brass' indirect method are similar to the ones using the own-children method. Graph 2 depicts age specific fertility rates for women at 
reproductive ages in 1980, 1991 and 2000 by income class and in the total population. The dotted line represents the Brazilian standard of fertility, the traced line corresponds to a third estimate of fertility using Mortara's (1949) method, and the line marked by little circles corresponds to the average fertility of Brass' indirect method and the own children method. The estimates using Mortara's methods were not considered in the calculation of the average fertility because they are not compatible or close to the other results.

Graph 2 shows two reassuring results. First, the fertility of the poor is above the average Brazilian standard while the fertility of the rich is way below it. In 1980, the average number of children born to women in the poor class was more than two-fold the total fertility of the middle class, while the fertility of the rich was almost one third of the middle class fertility. Second, the fertility estimates for the entire country are close to the official Brazilian census estimates and also similar to the estimates by MirandaRibeiro (2007), who estimated total fertility rates equal to 4 children in 1980; 2.71 in 1991; and 2.21 children in 2000 . The fact that our sample considers only individuals who had valid values of income might explain the small differences between their estimates and ours. ${ }^{6}$

The other picture emerging from these estimates shows the speed at which fertility fell in each income class between 1980 and 2000. The decline is particularly evident in the case of the poor class, where total fertility shifted from 6.53 to 3.78 children

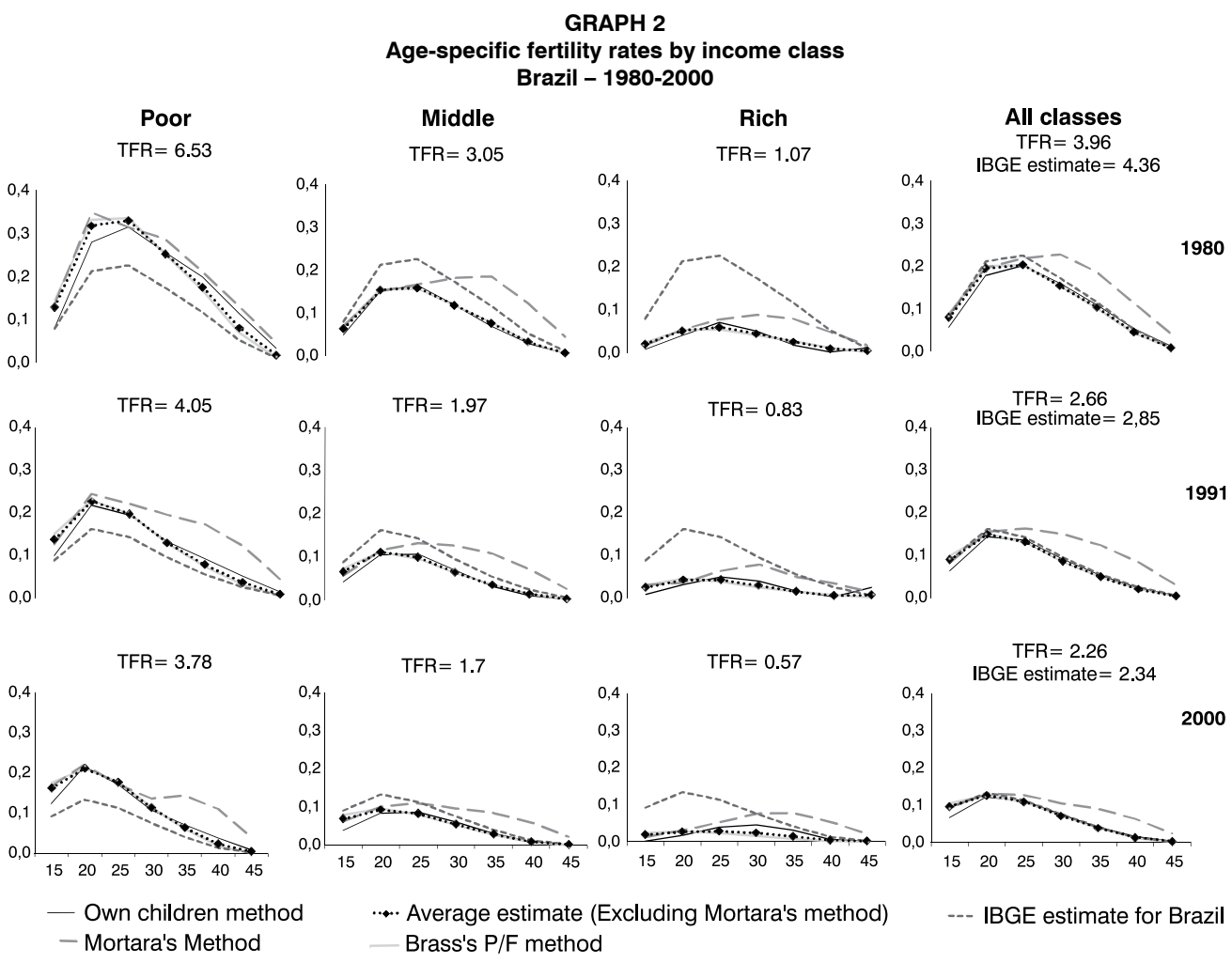

Source: Self-elaboration based on the 1980, 1991 and 2000 Brazilian Census.

\footnotetext{
${ }^{6}$ Age-specific fertility rates for each income class and for Brazil as a whole are in Appendix A.
} 
for every poor woman. In the rich class the decline also happened despite the fact that this class already had levels of fertility below replacement in 1980. Average fertility in the rich class declined from 1.07 to 0.57 between 1980 and 2000.

\section{Age-specific mortality by year and income} class

Life expectancies at birth in Brazil were equal to 62 years in 1980 and increased to 66 , ten years later. In 2000 , life expectancy at birth increased even more, shifting to 70.4 years according to IBGE official estimates. Overall, life expectancies over the life cycle were very similar for middle and poor classes. In contrast, the rich class had a much lower mortality in all age groups, although there is some noticeable convergence at older ages. In 2000, the difference between life expectancies became more evident as the gap between poor and rich classes increased and the gap between middle and rich classes decreased. This result is visually noticeable in Graph $3 .^{7}$

\section{GRAPH 3}

Age-specific death probabilities by income class

Brazil - 1980-2000

Poor class

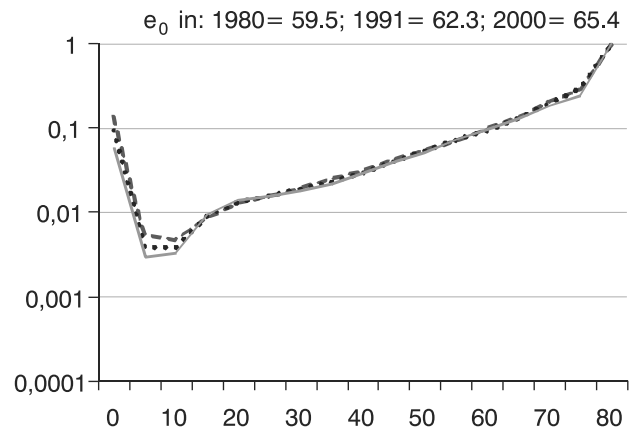

ס्र

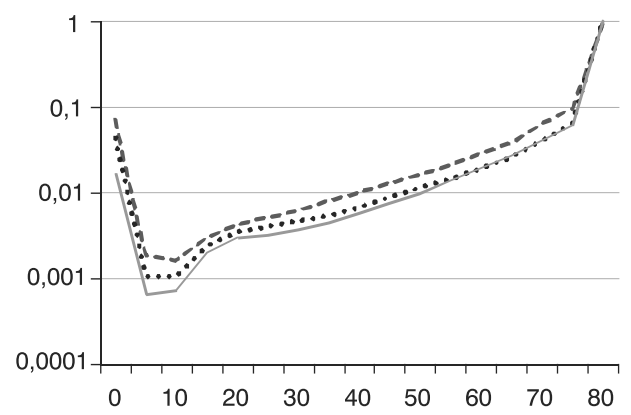

Middle class

$e_{0}$ in: $1980=62.4 ; 1991=66.5 ; 2000=71$

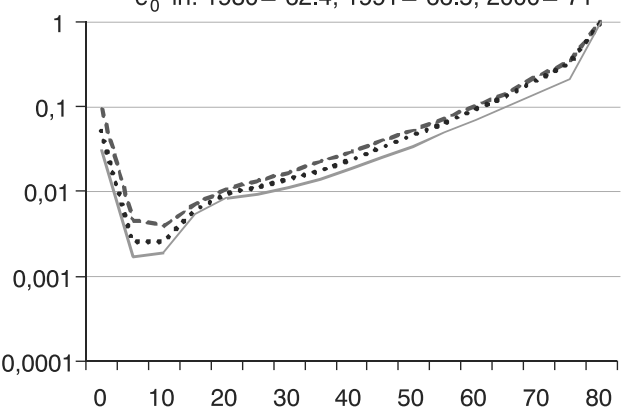

All classes

$e_{0}$ in: $1980=62.07 ; 1991=65.3 ; 2000=68.8$ IBGE: $1980=62.50 ; 1991=66 ; 2000=70.4$

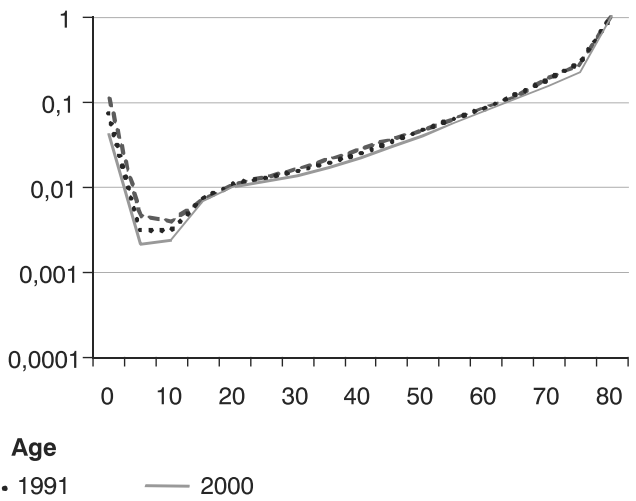

Source: Self-elaboration based on the 1980, 1991 and 2000 Brazilian Census.

\footnotetext{
7 Life expectancies and other parameters of the period life table by income class and for Brazil as a whole are available in Appendixes B and C.
} 
The mortality gap in life expectancies at birth between poor and rich classes, which was already large in 1980 - 13.6 years - increased even more in 2000 , shifting to 14.3 years. This increase is due to the fact that mortality decreased more among the rich than in the poor class during this period. While the life expectancy at birth of the poor increased 5.9 years between 1980 and 2000 , the life expectancy of the rich increased 6.6 years. Most of these gains in survivorship happened in the first year of life, regardless of social class. The mortality of children below one year of age fell from 135 deaths in 1950, to 63 in 1980, 42.5 in 1990 and 34 deaths for every thousand children born alive in 2000 (UNITED NATIONS, 2008). Gains in life expectancy in other ages were more significant for the middle class in 2000.

\section{Net reproduction and intrinsic growth} rates by year and income class

This section introduces reproduction measures and the intrinsic growth rate of groups belonging to different income classes in 1980, 1991 and 2000. The most important demographic measure of reproduction is the net reproduction rate (NRR), which takes mortality into account to indicate how successive generations replace themselves. It is "the average number of daughters that female members of a birth cohort would bear during their reproductive life span if they were subject to the observed age-specific maternity and mortality rates throughout their lifetimes" (PRESTON et al., 2001). These net rates indicate whether the female population is reproducing or replacing itself, and is usually a good indicator of how fertility and mortality combine to define population dynamics. Net reproduction rates greater than one mean that a cohort of baby girls will give birth to a generation of daughters larger than their own. In this case the population more than replaces itself from natural increase across consecutive generations. A NRR of one implies that a female population is replacing itself, and a NRR below one indicates that the female population will shrink in size over time if fertility and mortality remain stable over time.

The second term introduced in this section is the intrinsic or stable growth rate. The intrinsic growth rate measures how much the population would grow if current fertility and mortality patterns were to prevail in the future. It represents the annual growth rate that will eventually apply if fertility and mortality remain constant over time. Table 1

TABLE 1

Comparison between observed and stable-equivalent population parameters Brazil - 1980-2000

\begin{tabular}{|c|c|c|c|c|c|c|c|}
\hline \multirow{2}{*}{ Social class } & \multirow{2}{*}{ NRR } & \multicolumn{3}{|c|}{ Intrinsic rates } & \multicolumn{3}{|c|}{ Crude rates } \\
\hline & & $\mathbf{r}$ & b & d & CRNI & CBR & CDR \\
\hline \multicolumn{8}{|l|}{1980} \\
\hline Poor & 2,7583 & 0,0366 & 0,0462 & 0,0096 & 0,0283 & 0,0385 & 0,0102 \\
\hline Middle & 1,3476 & 0,0107 & 0,0223 & 0,0116 & 0,0179 & 0,0266 & 0,0087 \\
\hline Rich & 0,4973 & $-0,0239$ & 0,0042 & 0,0281 & 0,0050 & 0,0102 & 0,0053 \\
\hline \multicolumn{8}{|l|}{1990} \\
\hline Poor & 1,7729 & 0,0217 & 0,0310 & 0,0093 & 0,0202 & 0,0288 & 0,0086 \\
\hline Middle & 0,9035 & $-0,0038$ & 0,0126 & 0,0163 & 0,0101 & 0,0180 & 0,0079 \\
\hline Rich & 0,3863 & $-0,0329$ & 0,0024 & 0,0353 & 0,0015 & 0,0078 & 0,0063 \\
\hline \multicolumn{8}{|l|}{2000} \\
\hline Poor & 1,6951 & 0,0207 & 0,0295 & 0,0088 & 0,0246 & 0,0304 & 0,0058 \\
\hline Middle & 0,7930 & $-0,0088$ & 0,0098 & 0,0186 & 0,0074 & 0,0152 & 0,0078 \\
\hline Rich & 0,2784 & $-0,0446$ & 0,0011 & 0,0457 & 0,0011 & 0,0047 & 0,0035 \\
\hline
\end{tabular}

Source: Self-elaboration based on the 1980, 1991 and 2000 Brazilian Census. 
shows intrinsic growth rates, crude rates of natural increase, and net reproduction rates for the poor, middle and rich classes in 1980 , 1991 and 2000.

Table 1 shows that 1990 is the year when the Brazilian middle class would have made a transition to replacement if only fertility and mortality were contributing to the growth of this socioeconomic class (e.g. without considering social mobility between income classes). In 1990 the NRR of the middle class was equal to 0.903 daughters per woman. The rich class continued to decline, with a NRR much lower than 1 (0.386). In contrast, the poor was the only class that was more than replacing itself between 1980 and 2000 , although this rate of replacement substantially declined from 2.76 in 1980 to 1.69 in 2000 , representing a decline of 39 per cent.

The discrepancy between intrinsic and crude rates of natural increase indicates how close these populations are from stability. Large disparities between these rates mean that large changes in fertility and/or mortality have occurred in the histories of these populations. If the difference between natural and intrinsic growth is smaller, then past changes in mortality and fertility have not destabilized these population structures. Overall, all income classes have had positive growth since the 1980 s, but if mortality and fertility remain stable, rich and middle classes will eventually decline. Table 1 shows that the difference between intrinsic $(r)$ and crude rates of natural increase $(C R N I)$ is larger for the richest share of the population, which indicates that past changes in fertility and mortality have been more important in affecting the age structure of the rich than of other social classes. The rate of natural increase would eventually fall and become negative for the rich and middle classes if mortality and fertility conditions of 1990 and 2000 were maintained in the future. In other words, if current demographic rates were to prevail as observed in 1990 or 2000 , the mortality component would dominate the growth dynamics of the middle and rich classes, and as a result these subpopulations would decrease and eventually head to extinction.
Stable population scenarios such as the ones described in this section are an important tool to evaluate how populations will change if fertility and mortality remain constant over a long time period - about 100 years. For more immediate scenarios, it is perhaps more useful to examine how the population would look had fertility or mortality changed or remained constant for a shorter period of time. Projections offer an alternative to validate demographic estimates and infer the impact of fertility and mortality in a given period of time according to certain assumptions. The next section introduces demographic projections to demonstrate how the poor, middle and rich classes would grow if mortality and fertility were the only forces acting in population dynamics.

Demographic projections by income class.

Projections are useful to analyze the effects of a set of demographic parameters for population size, composition, and growth. Population projections illustrate the implications of certain demographic characteristics - assumptions about the future course of fertility and mortality on future population development and parameters over time. The goal of this section is to establish an empirical link between fertility, mortality and reproduction to show how class specific populations would have grown if only mortality and fertility estimated between 1980 and 2000 were dictating the growth dynamics of the poor, middle and rich classes.

The first things to consider in demographic projections are the assumptions of fertility and mortality for the projection period. The level and structure of mortality adopted in the projections reflect the average life table of each period. For the projection from 1980 to 1990 , we apply the average life table of these years, and for the projection period between 1990 and 2000 we use the average life tables of 1990 and 2000 . The assumption behind these estimates is that mortality will hold constant and equal to the average life table over each one of these decades. In the case of fertility, we allow a gradual and 
linear decline for each projection period of five years. Fertility and mortality for the poor, middle, and rich classes are reported in Table 2, where we also show the assumptions for the projection of the total population.

The first projection period, from 1980 to 1985 , assumes total fertility rate equal to 6.53 children per women and life expectancy at birth equal to 60.93 years for the poor class. In the subsequent projection period, from 1985 to 1990 , the mortality assumption remains the same, but total fertility rate declines to 5.40 children. This decline accommodates a more realistic scenario for the decade than assuming constant fertility over time. The resulting projections for the total population and for subpopulations by income class are in the graph below.

Graph 4 shows that the total projected population and the projection resulting from the sum of individual income class projections are very similar. The projections for the total population are accurate and in fact have a smaller error than the official projections conducted by IBGE (OLIVEIRA; ALBUQUERQUE; LINS, 2004). The small differences between projected and observed populations are due to international migration. By looking at class specific projections the following conclusions emerge:

- Overall, the projections by income class are not as accurate as the projection for the total population. The discrepancy between projected and observed populations is mostly due to social mobility between income classes. Given migration between classes (e.g. social mobility) is not considered in the projection models, projected and observed populations by class differ. So comparing observed and projected populations allows one to anticipate what was the contribution of social mobility to the growth of income specific social classes;

- The projection of the middle class is the closest to what was observed because this class also represents the largest share of the total population. In contrast, the projection of the rich class deviates from what was observed because it accounts for only one per cent of the total population. As a result, the projection of the rich class has a larger margin of error than the projection of the poor and middle classes;

- The projection of the poor class underestimates the growth of this class during the 1980s because a significant share of the population was moving into this class as a result of unfavorable economic circumstances. During the 1990s, the size of the poor class is overestimated in the projections because a significant share of the population left the "state of poverty" mainly as a result of

TABLE 2

Fertility and mortality assumptions by income class Brazil, 1980-2000

\begin{tabular}{|c|c|c|c|c|c|}
\hline Social class & 1980 & 1985 & 1990 & 1995 & 2000 \\
\hline \multicolumn{6}{|l|}{ TFR } \\
\hline Poor & 6,53 & 5,40 & 4,05 & 3,91 & 3,78 \\
\hline Middle & 3,05 & 2,56 & 1,97 & 1,83 & 1,70 \\
\hline Rich & 1,07 & 0,96 & 0,83 & 0,70 & 0,57 \\
\hline All Classes & 3,96 & 3,37 & 2,66 & 2,46 & 2,26 \\
\hline \multicolumn{6}{|l|}{$\mathrm{e}^{\mathrm{x}}{ }_{0}$} \\
\hline Poor & \multicolumn{2}{|c|}{60,93} & \multicolumn{2}{|c|}{63,88} & 65,43 \\
\hline Middle & \multicolumn{2}{|c|}{64,46} & \multicolumn{2}{|c|}{68,76} & 71,01 \\
\hline Rich & \multicolumn{2}{|c|}{75,14} & \multicolumn{2}{|c|}{78,43} & 79,71 \\
\hline All Classes & \multicolumn{2}{|c|}{63,71} & \multicolumn{2}{|c|}{67,04} & 68,76 \\
\hline
\end{tabular}

Source: Self-elaboration based on the 1980, 1991 and 2000 Brazilian Census. 
GRAPH 4

Projection of total population, poor class, middle class, and rich class Brazil - 1980- 2000

Projection 1980 to 1990
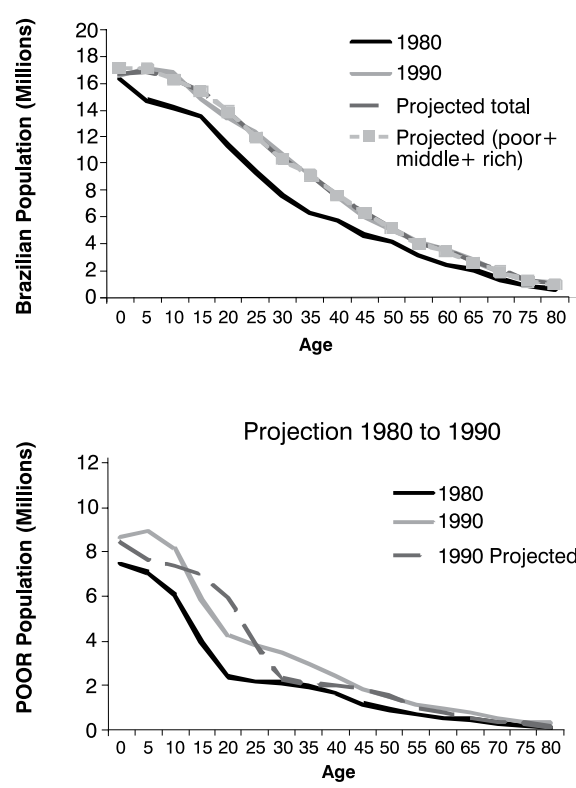

Projection 1980 to 1990

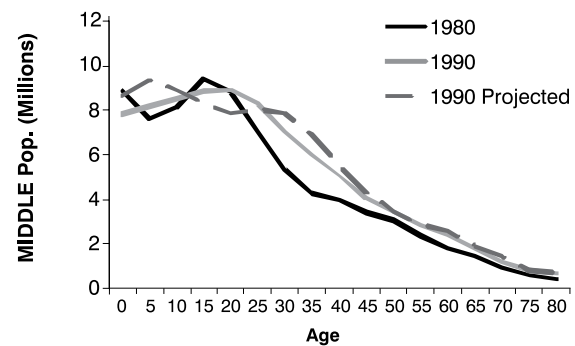

Projection 1980 to 1990

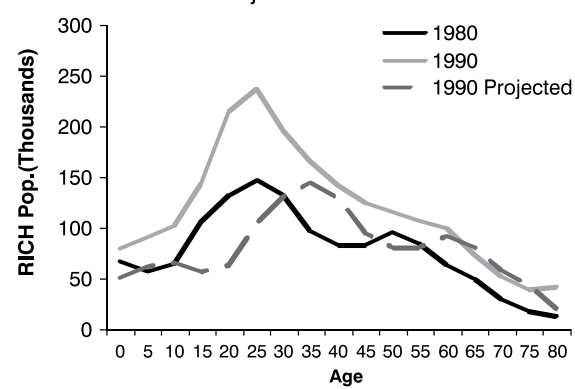

\section{Total population}

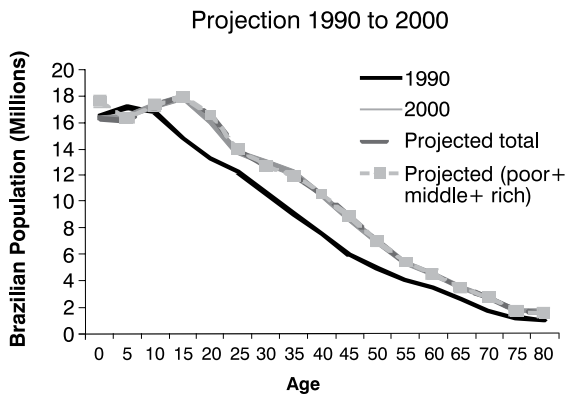

Poor class

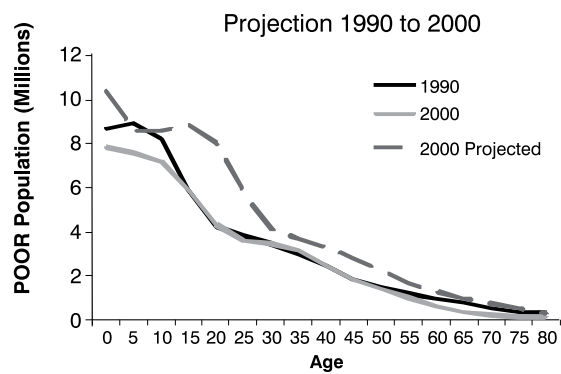

Middle class

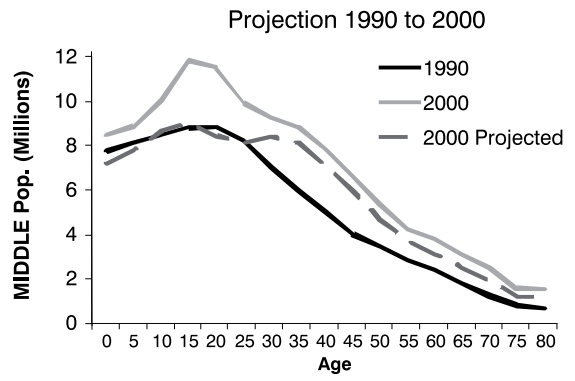

Rich class

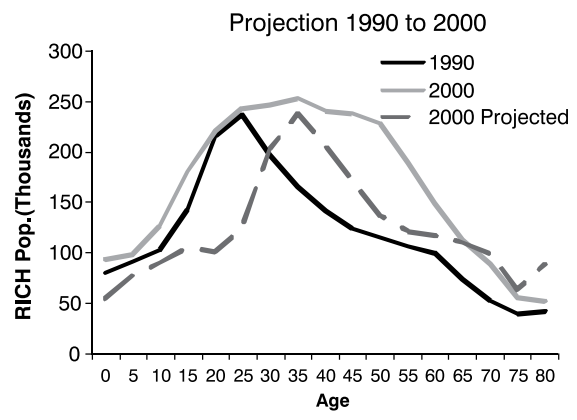

Source: Self-elaboration based on the 1980, 1991 and 2000 Brazilian Census. 
multiple anti-inflationary plans and the modernization of the economy.

- The projections overestimated the growth of the middle class in the 1980s and underestimated it in the 1990s. During the Brazilian "lost decade" many people moved from the middle to the poor class, and these moves are not captured or reflected by the fertility or mortality assumptions of the projection model. As a result, the projected middle class is larger than it actually was in 1990. In contrast, the projection of this class was underestimated in the 1990s. The share of the middle class in the total population expanded from 62 per cent in 1990 to 72 per cent in 2000, but this increase was not fully captured by the projection assumptions. The improvement in the economic condition of the poor class in the 1990s is not reflected in the population projections of the middle class;

- The rich class was underestimated in both projection periods. The size of the rich class is larger than the predicted for two reasons: first, because unfavorable inflationary shocks affecting the vast majority of the population in the 1980s did not have the same effect on the richest one per cent share of the Brazilian population. Because of their easier access to financial and physical investments, the rich were less vulnerable to adverse economic shocks than those at the bottom of the income distribution. Second, because the rich class represents only one per cent of the population, the fertility and mortality assumptions adopted in the projections are more vulnerable to changes over the period than in classes where the share of the population is larger and consequently more stable over time. The lesson is simple and well known to demographers: small populations and populations of small areas are hard to project with only fertility and mortality because they usually are very exposed to migration flows. This is exactly what the rich class represents in the projection context: a small share of the population that is heavily affected by the entrance of individuals from middle and poor classes who have faced upward mobility and who became part of the rich class during the 1980s and 1990s.

\section{The impact of demography on poverty and inequality}

One strategy to measure the impact of differential demographic rates over the size, composition and growth of specific income classes consists of comparing projected and observed populations in 1990 and 2000. Table 3 shows how much the poor population would increase under the assumptions of fertility and mortality adopted in the projections.

The second column of Table 3 shows that the poor population would increase by

TABLE 3

Comparison between projected and observed poor populations

\begin{tabular}{lrrrrr}
\hline & \multicolumn{2}{c}{1990} & & \multicolumn{2}{c}{2000} \\
\cline { 2 - 3 } \cline { 5 - 6 } & Projected & Observed & & Projected & Observed \\
\hline Size & & & & & \\
Count & 53.462 .077 & 56.326 .296 & & 71.859 .742 & 51.336 .620 \\
(Poor/ Total) (1) & 0,3712 & 0,3916 & & 0,4201 & 0,3001 \\
Poor/ Poor & 1,35 & 1,43 & & 1,28 & 0,91 \\
Keyfitz's Daseline & 0,11 & 0,06 & & 0,08 & 0,04 \\
\hline
\end{tabular}

Source: Self-elaboration based on the 1980, 1991 and 2000 Brazilian Census.

(1) The proportion of the poor in the total population includes individuals whose income was missing or equal to zero.

(2) Compares the age structure of projected and observed populations to the age structure of the baseline population/ Maximum value is 1 and minimum is 0 when the vectors are identical. 
35 per cent between 1980 and 1990 and account for 37 per cent of the total population if fertility and mortality were the only factors influencing the growth dynamics of the poor. Overall, the projection underestimates the census population by five per cent. If social mobility to and from the poor class had been taken into account, the projection of the poor population would have the same size as the observed poor population, described in column 3 . In contrast, the population projected in 2000 is overestimated by 40 per cent. If upward mobility had not been so intense in the 1990s, the poor population would have increased by 28 per cent and would account for about 42 per cent of the total population.

The last row of Table 3 reports Keyfitz's $\Delta$, which is a standard measure of the distance between probability vectors representing the proportion of the population in different ages. ${ }^{8}$ It indicates how different the age structures of projected and observed censual populations are in relation to the projection baseline. Overall, the age structure at the baseline is more similar to the age structure of the observed than to the projected populations. The internal structure of the population is less similar to the age structure observed ten years earlier when social mobility is absent from the model. This result is also confirmed by Graph 4, which shows a detailed comparison between observed and projected populations by age.

\section{Population impact on income inequality}

The impact of differential demographic growth on inequality involves two variables: income and population. The effect of demographic growth on inequality requires assumptions of independence between population and income and the establishment of rules dictating a behavior for the relationship between income and population. Since income inequality is not only a function of population, but also a function of how incomes are distributed among its members, in order to calculate income inequality and evaluate the role of demography we assume two counterfactual scenarios for income: in the first scenario the mean level of income remains the same as in the baseline of the projection. In the second scenario, the level of income is assumed to be the same as in the observed population at the end of the projection period. In both scenarios we used the projected population share in each income class to build the inequality counterfactuals. The aim of these simulations is to demonstrate how much inequality would change if populations shares of the poor, middle and rich classes were identical to those provided by the projections, while keeping class specific levels of income at their mean values in a given year. The results of these simulations are in Table 4.

Table 4 demonstrates how $\mathrm{GE}(0)$, the mean log deviation of income, is mostly a consequence of differences between the mean income of the class partition than of differences in the distribution of income within income classes. It also shows how inequality would change under different combinations of population and income. The first row, for instance, indicates that if the projected population in 1990 was combined with the income level of 1980 , total inequality would be five per cent higher (0.83) than in 1991 (0.786). Using the mean level of income of 1991 in the simulation, inequality is only 0.54 per cent lower than in 1991 (0.786 and 0.7909, respectively). Ceteris paribus, this result suggests that income inequality should have been slightly lower in 1991 if mortality and fertility were the only components dictating the population dynamics of the period. The simulated level of inequality (0.78) would still be higher than in 1980 (0.72, not reported), but it would be lower than the inequality generated by mortality, fertility and mobility in 1991 (0.79).

\footnotetext{
${ }^{8}$ Keyfitz (1968, p. 47) proposed a measure equivalent to $\Delta(x, w)=\frac{1}{2} \sum_{i}\left|x_{i}-w_{i}\right|$, where $x$ is the proportion of the poor population at the baseline; wi is the proportion of the population in the projected or observed population ten years after the baseline, and i describes five-year age groups between 0 and 80 .
} 
TABLE 4

Simulated income inequality due to differential population increase

\begin{tabular}{|c|c|c|c|c|}
\hline \multicolumn{2}{|c|}{ Inequality inputs: } & \multicolumn{2}{|c|}{$\mathrm{GE}(0)(1)$} & \multirow[b]{2}{*}{ Total } \\
\hline Populationshare & Income & Within (2) & Between & \\
\hline 1990 projected & 1980 & 0,2621 & 0,5600 & 0,8220 \\
\hline 1990 projected & 1991 & 0,2707 & 0,5065 & 0,7772 \\
\hline 1990 observed & 1991 & 0,2645 & 0,5477 & 0,8122 \\
\hline 1991 observed (3) & 1991 & 0,2687 & 0,5222 & 0,7909 \\
\hline 2000 projected & 1991 & 0,2580 & 0,6247 & 0,8827 \\
\hline 2000 projected & 2000 & 0,2656 & 0,8424 & 1,1080 \\
\hline 2000 Fullsample & 2000 & 0,2916 & 0,5716 & 0,8632 \\
\hline 2000 observed (3) & 2000 & 0,3009 & 0,4777 & 0,7786 \\
\hline
\end{tabular}

Source: Self-elaboration based on the 1980, 1991 and 2000 Brazilian Census.

(1) GE $(0)=$ Theil-L index $=$ mean log deviation $=\frac{1}{n} \sum_{i=1}^{n} \ln \frac{\mu}{y_{i}}$, where $\mathrm{n}$ is the number of individuals in the sample, $\mathrm{y}_{\mathrm{i}}$ is the income of individual $\mathrm{i}, \mathrm{i} \in(1,2, \ldots, \mathrm{n})$ and $\mu=1 / n \sum y_{i}$ is the arithmetic mean income. The inequality index $\mathrm{GE}(0)$ gives slightly more weight to distances between incomes in the lower tail. Total inequality (I) can then be expressed as a direct sum of between ( $I_{B}$ ) and within $\left(I_{W}\right)$ inequalities, $I=I_{W}+I_{B}$. For each class of generalized inequality index, within and between inequalities are defined as: $G E(0)=I_{W}^{G E(0)}+I_{B}^{G E(0)}=\sum_{j=1}^{k} f_{j} G E(0)_{j}+\sum_{j=1}^{k} f_{j} \ln \left(1 / \lambda_{j}\right)$, where is the population share and is the mean income of each subgroup $\mathrm{j}, \mathrm{j}=$ poor, middle, rich, relative to that of the whole population. The first term represents within inequality and is simply the sum of subgroup inequalities weighted by population and the relative mean income shares. The second term, inequality between subgroups, reflects differences in the subpopulation means. In decompositions by income class this term corresponds to the pure "class effect".

(2)Within income, inequality of poor, middle and rich classes is kept constant. Only the between component of inequality varies to create counterfactual scenarios with different mean incomes and population shares for a given year.

(3) Excludes observations with missing and income values equal to zero.

In 2000, the counterfactual scenarios show the opposite of what was observed ten years earlier. Depending on the level of income and within inequality assumed in the simulation (e.g. 1991 or 2000) the projected population in 2000 provides inequality levels between $13(0.87)$ and 40 (1.09) per cent higher than what was estimated in 2000 $(0.7786)$. Thus, if there was no mobility between social classes during the 1990s, income inequality would have been higher than it actually was.

The evidence in Table 4 suggests that income inequality moves in the same direction as the size of the poor population. In 1991, simulated income inequality and the projected poor population are lower than what was observed. In 2000 , the opposite happened: the projected poor population was overestimated and so was inequality. The social mobility happening in the 1980s, mostly from the middle to the poor class, helped to increase income inequality in 1990 , from 0.78 to 0.79 . In the 1990 s, there was a shift in this trend since there were more people moving out of the poor class than into it. As a result of upward mobility, income inequality decreased by 29 per cent (from 1.09 to 0.77 ). Overall, the impact of net social mobility on inequality was stronger in the 1990s than in the 1980s.

\section{Summary and conclusion}

This study answered the following questions: 1) what are the fertility and mortality rates of socially distinct economic groups? 2) How much would the poor, middle and rich classes grow under the demographic conditions of the 1980s and 1990s? 3) How would poverty and income inequality change under these demographic circumstances?

The evidence answering the first question shows that the fertility gap between the poor and rich classes was 3.2 children in 2000 , despite the fast decline of fertility in the poor class during the 1980 s. The total fertility rate 
of the poor shifted from 6.53 to 3.78 children between 1980 and 2000, while in the rich class it shifted from 1.07 to 0.57 during the same period. Mortality also declined in all classes and contributed to increase life expectancy. The gains in life expectancy at birth were more evident in the middle class, where one could expect to live 62.4 in 1980 and 71 years in 2000 - a gain of almost 9 years. The rich had a gain of 6.6 years during this same period (73.1 to 79.7 years), and the poor had a gain of about 6 years in life expectancy at birth between 1980 and 2000 (from 59.5 to 65.4 years). This differential increase in life expectancy at birth contributed to increase the mortality gap between poor and rich classes from 13.6 to 14.3 expected years of life.

Combining fertility and mortality produces net reproduction rates for each income class. These rates indicate that most population growth is due to the reproduction of the poor class, where the NRR was equal to 2.76 in 1980 and 1.69 in 2000. In the middle class it has been below replacement since 1990 and in the rich, since prior to 1980 . The rich class also is the one with the most unstable growth. Since the difference between intrinsic and crude rates of natural increase is larger for the richest share of the population, past changes in fertility and mortality have been more important in affecting the age structure of the rich than of the middle and poor classes.

The answer to the second question derives from demographic projections. The multi- and single-state projections of the total population provide similar results. The projection of class specific populations, however, differs from what was expected because the cohort-component projection method does not take into account the mobility of individuals between income classes and international migration. While the effect of international migration has little effect on the projections, the entrance of individuals into the poor class (e.g. downward social mobility) in the 1980s contributed to increase the size of the poor population. As this mobility is not considered in the projections, the size of the poor population is underestimated in 1990. By this same logic, the projected poor population is overestimated in 2000 because of the intense exit (e.g. upward mobility) of people from the poor class in the 1990s, a period marked by intense anti-inflationary plans and industrialization. Most of these population exchanges occurred between middle and poor classes since the rich group accounted for only a small share of the total population (roughly one per cent). Because of its small participation in the total population, the rich is the most unstable group and the hardest to project. The rich population was underestimated in both projection periods because thousands of individuals moved into the rich class in the 1980s and 1990s.

The projection exercise also answers the third question. If the fertility and mortality values estimated in 1980 and 1990 were the only forces contributing to the demographic dynamics of the period, the poor population would have increased by 35 per cent instead of 43 per cent, which was the real growth between 1980 and 1990. Between 1990 and 2000 the poor would have increased by 28 per cent due to demographic forces. However, because this was also a period of intense upward social mobility from the poor to other classes, the poor class shrank. The actual size of the poor group in 2000 was 91 per cent of the one observed ten years earlier.

The projection approach allowed the construction of counterfactual scenarios to measure how income inequality would have changed if projected populations were used in the measurement of inequality. Ceteris paribus, income inequality would be slightly lower (0.78 versus 0.79 ) in 1991 if the population had grown only according to mortality and fertility. In contrast, income inequality in 2000 would have been higher than what was actually observed in the census count if the population had followed the path defined by the demographic assumptions of the model (1.09 versus 0.77 ). This evidence corroborates the following conclusions about the role of social mobility: a) in the 1980s, the downward mobility to the poor class helped to increase the level of income inequality in 1990 from 0.78 to 0.79 ; b) in the 1990s, upward mobility, especially from the poor to the middle class, helped 
to alleviate income inequality, from 1.09 to 0.77 . In brief, the impact of social mobility on income inequality was more intense in the 1990 s than in the 1980s. These conclusions, however, are valid only to the extent that the mortality and fertility estimates from which they derive are precise. Since classspecific projections are a direct result of the estimates of fertility and mortality obtained through indirect demographic methods, the validity of the conclusions described here is also conditioned to the accuracy and robustness of the methods. The impact of these estimates on the net mobility is that, if class-specific fertility was underestimated, the level of mobility to that class, in the first age-groups, will be exaggerated. And if class-specific mortality is underestimated, social mobility into that class would look smaller than it actually was if mortality had been accurately measured.

In the absence of alternative methods, comparable and better data to validate estimates, it is impossible to precise the size of bias included in the estimates of fertility and mortality. All the information available in the Brazilian censuses was used to generate and validate the demographic parameters of class-specific fertility and mortality. Moreover,

\section{References}

BRASS, W.; COALE, A.; DEMENY, P.; HEISEL, D.; LORIMER, F.; ROMANIUK, A.; VAN DE WALLE, E. The demography of Tropical Africa. Princeton, N.J.: Princeton University Press, 1968.

BRASS, W. On the scale of mortality. In: BRASS, W. (Org.). Biological aspects of demography. London: Taylor and Francis Ltd; New York: Barnes \& Noble Inc., 1971, p. 69-110.

BROCKERHOFF, M.; BRENNAN, E. The poverty of cities in developing regions. Population and Development Review, v. 24, n. 1, p. 75-114, 1998.

CAMARANO, A.; BELTRÃO, K. Dinâmica demográfica por nível de renda. Revista Brasileira de Estudos Populacionais, v. 12, n. 1/2, 1995. the indirect methods employed in the analysis are well known and recognized among demographers as the best option to measure fertility and mortality rates in the absence of directly observable data. Total estimates of fertility and mortality for Brazil as a whole are similar to those provided by IBGE and close to the ones in the literature (MIRANDA-RIBEIRO, 2007). Despite the intrinsic uncertainties of the method, we believe that the estimates are as good as they could get given the current tools of Demography.

All the results and conclusions presented in this study assume that fertility and mortality are the only forces affecting the dynamics of growth of income specific classes. This restrained analysis is useful because it portrays population growth in the absence of social mobility. Future research, however, should take a closer look at the influence of mobility on population growth and calculate how the poor, middle and rich classes have changed their sizes when they are allowed to move between these three groups. It would be interesting to investigate the net reproduction rate, life expectancies and stable growth rates when mobility becomes an explicit component of the demographic dynamics.

CHO, L.-J.; RETHERFORD, R.; CHOE, $M$. The own-children method of fertility estimation. Honolulu, $\mathrm{HI}$ : Population Institute, 1986.

CHU, C.; JIANG, L. Demographic transition, family structure, and income inequality. Review of Economics and Statistics, v. 79, n. 4, p. 665-669, 1997.

$\mathrm{CHU}, \mathrm{C}$; $\mathrm{KOO}, \mathrm{H}$. Intergenerational incomegroup mobility and differential fertility. American Economic Review, v. 80, n.5, p. 1125-1138, 1990.

CORSEUIL, C.; FOGUEL, M. Uma sugestão de deflatores para rendas obtidas a partir de algumas pesquisas domiciliares do IBGE. Brasília: Ipea, 2002 (Texto de discussão, 897). 
COWELL, F.; JENKINS, S. How much inequality can we explain: a methodology and an application to the United-States. Economic Journal, v. 105, n. 429, p. 421 430, 1995.

DATTA, G.; MEERMAN, J. Household income or household income per capita in welfare comparisons. Review of Income and Wealth v. 26, n. 4, p. 401-418, 1980.

DE LA CROIX, D.; DOEPKE, M. Inequality and growth: why differential fertility matters. American Economic Review, v. 93, n. 4, p. 1091-1113, 2003.

FEENEY, G. The own-children method of estimating age-specific fertility rates. In: DEMOGRAPHIC ANALYSIS AND DATA EVALUATION WORKSHOP. Department of Statistics, Kuala Lumpur, 1975.

FERREIRA, F.; BARROS, R. The slippery slope: explaining the increase in poverty in urban Brazil, 1976-1996. Washington, DC: World Bank Poverty Reduction and Economic Management Network Poverty Division, 1999.

FERREIRA, F.; LANJOUW, P.; NERI, M. A new poverty profile for Brazil using PPV, PNAD and census data. Rio de Janeiro: Pontifícia Universidade Católica do Rio de Janeiro. Departamento de Economia, 2000 (Texto para discussão, n. 418).

FIORIO, C. Understanding inequality trends: microsimulation decomposition for Italy. STICERD DARP 78. London: London School of Economics, 2006.

FIRPO, S.; GONZAGA, G.; NARITA, R. Decomposição da evolução da desigualdade de renda no Brasil em efeitos idade, periodo e coorte. Pesquisa e Planejamento Econômico, v. 33, n. 2, p. 211-252, 2003.

GRUSKY, D.; SORENSEN, J. Can class analysis be salvaged? American Journal of Sociology, v. 103, n. 5, p. 1187-1234, 1998.

HAUSER, R.; WARREN, J. Socioeconomic indexes for occupations: a review, update, and critique. Sociological Methodology, v. 27, p. 177-298, 1997.
HILL, K.; TRUSSELL, J. Further developments in indirect mortality estimation. Population Studies, v. 31, n. 2, p. 313-34, 1977.

OLIVEIRA, J.; ALBUQUERQUE, F.; LINS, I. Projeção da população do Brasil por sexo e idade para o período $1980-2050$ - Revisão 2004: metodologia e resultados. Estimativas anuais e mensais da população do Brasil e das unidades da federação: 1980-2020 metodologia. Estimativas das populações municipais: metodologia. Rio de Janeiro: IBGE, 2004.

JENKINS, S. Accounting for inequality trends: decomposition analyses for the UK, 1971-86. Economica, v. 62, n. 245, p. 29-63, 1995 .

KEYFITZ, N. Introduction to the mathematics of population. Reading, Mass.: Addison-Wesley Pub. Co., 1968.

KREMER, M.; CHEN, D. L. Income distribution dynamics with endogenous fertility. Journal of Economic Growth, v. 7, n.3, p. 227-258, 2002.

LAM, D. The dynamics of population-growth, differential fertility, and inequality. American Economic Review, v. 76, n. 5, p. 1103-1116, 1986.

LESLIE, P. On the use of matrices in certain population mathematics. Biometrika, v. 33, n. 3, p. 183-212, 1945.

. Some further notes on the use of matrices in population mathematics. Biometrika, v. 35, n. 3/4, p. 213-245, 1948.

MARE, R. Differential fertility, intergenerational educational mobility, and racial inequality. Social Science Research, v.2 6, n. 3, p. 263-291, 1997.

MEDEIROS, M. O que faz os ricos ricos: o outro lado da desigualdade brasileira. São Paulo: Hucitec, 2005.

MIRANDA-RIBEIRO, A. Reconstrução de histórias de nascimentos a partir de dados censitários: aspectos teóricos e evidências empíricas. PhD Thesis, Centro de Desenvolvimento e Planejamento Regional, Faculdade de Ciências Econômicas, UFMG, 2007. 
MORTARA, G. Methods of using census statistics for the calculation of life tables and other demographic measures. United Nations Publication, Sales n. 1950. XIII.3, 1949, p. 40-60.

NERI, M. Assets, markets and poverty in Brazil. Escola de Pós-Graduação em Economia da Fundação Getúlio Vargas, 2000 (Coleção Ensaios Econômicos, n. 374).

PERO, V.; SZERMAN, D. Mobilidade intergeracional de renda no Brasil. In: XXXIII ENCONTRO NACIONAL DE ECONOMIA 146. Anais... Anpec - Associação Nacional dos Centros de Pós-graduação em Economia, 2005.

PRESTON, S.; CAMPBELL, C. Symposium on intergenerational transmission - differential fertility and the distribution of traits: the case of IQ. American Journal of Sociology, v. 98, n. 5, p. 997-1019, 1993.

PRESTON, S.; HEUVELINE, P.; GUILLOT, $M$. Demography: measuring and modeling population processes. Oxford; Malden, Mass.: Blackwell Publishers, 2001.

ROCHA, S. Estimação de linhas de indigência e de pobreza: opções metodológicas no Brasil. In: HENRIQUES, R.; BARROS, A.(Orgs.). Desigualdade e pobreza no Brasil. Rio de Janeiro: Ipea, 2000, p. 109127.

ROGERS, A. Matrix analysis of interregional population growth and distribution. Berkeley: University of California Press, 1968.

RUGGLES, S.; SOBEK, M.; ALEXANDER, T.; FITCH, C.; GOEKEN, R.; HALL, P.; KING, $\mathrm{M}$.; RONNANDER, $\mathrm{C}$. Integrated public use microdata series: Version 3.0 (machinereadable database). Minneapolis, $\mathrm{MN}$ : Minnesota Population Center, 2004.

SCHWARTZMAN, S. Vantagens e desvantagens das linhas de pobreza. 2002. Disponível em: <http://www.iets. org.br/article.php3?id_article $=266 \& v a r$ recherche $=$ pobreza $>$. Access on: Nov. 05, 2005.

SHORROCKS, A.; WAN, G. Spatial decomposition of inequality. Journal of Economic Geography, v. 5, n. 1, p. 59-81, 2005.

SORENSEN, A. On the usefulness of class analysis in research on social-mobility and socioeconomic inequality. Acta Sociologica, v. 34, n. 2, p. 71-87, 1991

UNITED NATIONS; Population Division of the Department of Economic and Social Affairs. World population prospects: the 2006 revision and world urbanization prospects. The 2005 revision. United Nations, 2008.

WOOD, C.; CARVALHO, J. The demography of inequality in Brazil. Cambridge; New York: Cambridge University Press, 1988.

WRIGHT, E. Class counts: comparative studies in class analysis. Cambridge; New York; Paris: Cambridge University Press; Maison des sciences de l'homme, 1997.

Press, 2005.

Approaches to class analysis. Cambridge, UK; New York: Cambridge University

\section{Resumo}

Dinâmica demográfica da pobreza e da desigualdade de renda: o caso do Brasil

Há uma crença comum de que as maiores taxas de reprodução dos pobres aumentariam os níveis médios de pobreza, causariam elevação da desigualdade, mitigariam o desenvolvimento econômico e reduziriam a mobilidade social ascendente. Para testar estas hipóteses, o presente estudo utilizou dados dos Censos brasileiros de 1980, 1991 e 2000. Além de apresentar as taxas de crescimento demográfico de subpopulações em diferentes níveis de renda (classes baixa, média e alta), este artigo também avalia o impacto do diferencial de taxas demográficas 
sobre o tamanho, a composição e o crescimento de classes específicas de renda e sobre a distribuição de renda a partir de projeções populacionais e traz análises de populações estáveis para demonstrar as implicações de longo prazo causadas pela manutenção ou alteração dos padrões demográficos correntes sobre a composição da pobreza e da desigualdade.

Palavras-chave: Pobreza. Desigualdade. Brasil. Mortalidade. Fecundidade. Taxas de reprodução.

\section{Resumen}

Dinámica demográfica de la pobreza y la desigualdad de renta: el caso de Brasil

Existe una creencia muy extendida de que unas mayores tasas de reproducción de los pobres aumentarían los niveles medios de pobreza, causarían un aumento de la desigualdad, mitigarían el desarrollo económico y reducirían la movilidad social ascendente. Para comprobar estas hipótesis, el presente estudio utilizó datos de los censos brasileños de 1980, 1991 y 2000. Además de presentar las tasas de crecimiento demográfico de sub-poblaciones con diferentes niveles de renta (clases baja, media y alta), este artículo también evalúa el impacto del diferencial de tasas demográficas sobre el tamaño, la composición y el crecimiento de clases específicas de renta y sobre la distribución de renta a partir de proyecciones poblacionales. Además, trae consigo un análisis de poblaciones estables para demostrar las implicaciones a largo plazo, causadas por el mantenimiento o alteración de los patrones demográficos corrientes, sobre la composición de la pobreza y de la desigualdad.

Palabras-clave: Pobreza. Desigualdad. Brasil. Mortalidad. Fecundidad. Tasas de reproducción.

Recebido para publicação em 20/03/2011 Aceito para publicação em 29/07/2011 
Appendix A. Age specific fertility rates by income class in Brazil, 1980, 1991 and 2000 Fertility Rates, POOR CLASS, Brazil

\begin{tabular}{crrc}
\hline Age group & $\mathbf{1 9 8 0}$ & $\mathbf{1 9 9 1}$ & $\mathbf{2 0 0 0}$ \\
\hline $15-19$ & 0.1292 & 0.1367 & 0.1620 \\
$20-24$ & 0.3186 & 0.2260 & 0.2117 \\
$25-29$ & 0.3305 & 0.1964 & 0.1765 \\
$30-34$ & 0.2527 & 0.1287 & 0.1136 \\
$35-39$ & 0.1756 & 0.0782 & 0.0640 \\
$40-44$ & 0.0816 & 0.0361 & 0.0236 \\
$45-49$ & 0.0176 & 0.0080 & 0.0042 \\
\hline Mean age at childbearing & 28.2437 & 27.4291 & 26.9774 \\
TFR & 6.5286 & 4.0504 & 3.7783 \\
\hline
\end{tabular}
Fertility Rates, MIDDLE CLASS, Brazil

\begin{tabular}{crrc}
\hline Age group & 1980 & 1991 & 2000 \\
\hline $15-19$ & 0.0633 & 0.0658 & 0.0694 \\
$20-24$ & 0.1543 & 0.1113 & 0.0931 \\
$25-29$ & 0.1594 & 0.0997 & 0.0829 \\
$30-34$ & 0.1182 & 0.0647 & 0.0550 \\
$35-39$ & 0.0761 & 0.0355 & 0.0287 \\
$40-44$ & 0.0322 & 0.0143 & 0.0088 \\
$45-49$ & 0.0060 & 0.0029 & 0.0014 \\
\hline Mean age at childbearing & 28.0837 & 27.6703 & 27.8183 \\
TFR & 3.0476 & 1.9707 & 1.6964 \\
\hline
\end{tabular}

Fertility Rates, RICH CLASS, Brazil

\begin{tabular}{crcc}
\hline Age group & $\mathbf{1 9 8 0}$ & $\mathbf{1 9 9 1}$ & $\mathbf{2 0 0 0}$ \\
\hline $15-19$ & 0.0202 & 0.0246 & 0.0187 \\
$20-24$ & 0.0513 & 0.0424 & 0.0260 \\
$25-29$ & 0.0595 & 0.0422 & 0.0282 \\
$30-34$ & 0.0442 & 0.0293 & 0.0234 \\
$35-39$ & 0.0255 & 0.0154 & 0.0141 \\
$40-44$ & 0.0095 & 0.0055 & 0.0036 \\
$45-49$ & 0.0046 & 0.0072 & 0.0008 \\
\hline Mean age at childbearing & 29.3978 & 28.7137 & 31.6932 \\
TFR & 1.0739 & 0.8332 & 0.5738 \\
\hline
\end{tabular}

Fertility Rates, ALL CLASSES, Brazil

\begin{tabular}{ccccccc}
\hline Age group & $\mathbf{1 9 8 0}$ & IBGE1980 & $\mathbf{1 9 9 1}$ & IBGE1991 & 2000 & \multicolumn{1}{c}{ IBGE2000 } \\
\hline $15-19$ & 0.0802 & 0.0797 & 0.0897 & 0.0874 & 0.0954 & 0.091 \\
$20-24$ & 0.1956 & 0.2130 & 0.1492 & 0.1618 & 0.1255 & 0.1335 \\
$25-29$ & 0.2034 & 0.2260 & 0.1316 & 0.1429 & 0.1082 & 0.1138 \\
$30-34$ & 0.1544 & 0.1730 & 0.0860 & 0.0941 & 0.0709 & 0.0751 \\
$35-39$ & 0.1036 & 0.1170 & 0.0496 & 0.0545 & 0.0382 & 0.0408 \\
$40-44$ & 0.0456 & 0.0526 & 0.0214 & 0.0243 & 0.0125 & 0.0133 \\
$45-49$ & 0.0088 & 0.0108 & 0.0045 & 0.0056 & 0.0020 & 0.002 \\
\hline Mean age at childbearing & 28.1714 & & 27.4875 & & 27.1613 & \\
TFR & 3.9579 & 4.3605 & 2.6597 & 2.8530 & 2.2636 & 2.3475 \\
\hline
\end{tabular}

Source: Self-elaboration based on the 1980, 1991 and 2000 Brazilian Census. 
Appendix B. Life expectancies by age and income class, Brazil 1980, 1991 and 2000

\begin{tabular}{|c|c|c|c|c|c|c|c|c|c|c|c|}
\hline \multicolumn{4}{|c|}{ Life expectancies, POOR class } & \multicolumn{4}{|c|}{ Life expectancies, MIDDLE class } & \multicolumn{4}{|c|}{ Life expectancies, $\mathrm{RICH}$ class } \\
\hline $\begin{array}{l}\text { Age } \\
\text { group }\end{array}$ & 1980 & 1991 & 2000 & $\begin{array}{c}\text { Age } \\
\text { group }\end{array}$ & 1980 & 1991 & 2000 & $\begin{array}{c}\text { Age } \\
\text { group }\end{array}$ & 1980 & 1991 & 2000 \\
\hline 0 & 59.51 & 62.33 & 65.43 & 0 & 62.39 & 66.53 & 71.01 & 0 & 73.12 & 77.16 & 79.71 \\
\hline 5 & 63.61 & 63.80 & 64.35 & 5 & 63.76 & 65.14 & 68.25 & 5 & 73.74 & 75.65 & 76.03 \\
\hline 10 & 58.94 & 59.04 & 59.53 & 10 & 59.03 & 60.30 & 63.36 & 10 & 68.88 & 70.73 & 71.08 \\
\hline 15 & 54.20 & 54.26 & 54.72 & 15 & 54.25 & 55.45 & 58.48 & 15 & 63.99 & 65.80 & 66.13 \\
\hline 20 & 49.64 & 49.73 & 50.20 & 20 & 49.61 & 50.77 & 53.78 & 20 & 59.17 & 60.96 & 61.26 \\
\hline 25 & 45.24 & 45.37 & 45.87 & 25 & 45.12 & 46.23 & 49.20 & 25 & 54.42 & 56.16 & 56.44 \\
\hline 30 & 40.90 & 41.05 & 41.56 & 30 & 40.69 & 41.73 & 44.65 & 30 & 49.69 & 51.38 & 51.61 \\
\hline 35 & 36.63 & 36.79 & 37.28 & 35 & 36.33 & 37.28 & 40.12 & 35 & 44.99 & 46.60 & 46.80 \\
\hline 40 & 32.49 & 32.60 & 33.07 & 40 & 32.10 & 32.91 & 35.65 & 40 & 40.34 & 41.84 & 42.00 \\
\hline 45 & 28.46 & 28.52 & 28.98 & 45 & 27.98 & 28.64 & 31.28 & 45 & 35.72 & 37.11 & 37.23 \\
\hline 50 & 24.58 & 24.59 & 25.05 & 50 & 24.03 & 24.53 & 27.03 & 50 & 31.16 & 32.41 & 32.49 \\
\hline 55 & 20.81 & 20.84 & 21.27 & 55 & 20.21 & 20.62 & 22.91 & 55 & 26.63 & 27.75 & 27.80 \\
\hline 60 & 17.20 & 17.24 & 17.68 & 60 & 16.58 & 16.89 & 18.96 & 60 & 22.16 & 23.12 & 23.15 \\
\hline 65 & 13.76 & 13.79 & 14.27 & 65 & 13.16 & 13.36 & 15.19 & 65 & 17.74 & 18.51 & 18.54 \\
\hline 70 & 10.42 & 10.50 & 11.00 & 70 & 9.91 & 10.09 & 11.59 & 70 & 13.36 & 13.94 & 13.98 \\
\hline 75 & 7.45 & 7.44 & 7.84 & 75 & 7.13 & 7.16 & 8.14 & 75 & 9.10 & 9.41 & 9.45 \\
\hline 80 & 4.46 & 4.48 & 4.54 & 80 & 4.44 & 4.49 & 4.66 & 80 & 4.82 & 4.89 & 4.90 \\
\hline
\end{tabular}

Life expectancies, ALL classes, BRAZIL

\begin{tabular}{ccccccc}
\hline Age group & 1980 & IBGE 1980 & $\mathbf{1 9 9 1}$ & IBGE1991 & $\mathbf{2 0 0 0}$ & IBGE2000 \\
\hline 0 & 62.078 & 62.511 & 65.334 & 66.026 & 68.763 & 70.457 \\
5 & 64.938 & 66.147 & 65.474 & 68.474 & 66.784 & 71.637 \\
10 & 60.225 & 63.196 & 60.669 & 64.568 & 61.926 & 68.114 \\
15 & 55.456 & 58.462 & 55.850 & 59.733 & 57.072 & 63.250 \\
20 & 50.841 & 53.678 & 51.236 & 54.888 & 52.451 & 58.390 \\
25 & 46.369 & 49.041 & 46.768 & 50.221 & 47.978 & 53.756 \\
30 & 41.950 & 44.548 & 42.345 & 45.692 & 43.526 & 49.275 \\
35 & 37.601 & 40.116 & 37.969 & 41.214 & 39.106 & 44.824 \\
40 & 33.371 & 35.767 & 33.657 & 36.794 & 34.739 & 40.415 \\
45 & 29.238 & 31.557 & 29.447 & 32.794 & 30.483 & 36.072 \\
50 & 25.253 & 27.473 & 25.379 & 28.230 & 26.362 & 31.859 \\
55 & 21.370 & 23.581 & 21.480 & 24.179 & 22.374 & 27.813 \\
60 & 17.645 & 19.846 & 17.731 & 20.344 & 18.567 & 23.942 \\
65 & 14.085 & 16.349 & 14.135 & 16.722 & 14.926 & 20.322 \\
70 & 10.640 & 13.126 & 10.722 & 13.340 & 11.431 & 16.971 \\
75 & 7.573 & 62.511 & 7.871 & 10.261 & 8.065 & 13.923 \\
80 & 4.510 & 66.147 & 65.334 & 7.634 & 4.621 & 11.292 \\
\hline
\end{tabular}

Source: Self-elaboration based on the 1980, 1991 and 2000 Brazilian Census. 
Appendix C. Life tables by age and income class, Brazil, 1980, 1991 and 2000

\begin{tabular}{|c|c|c|c|c|c|c|c|c|}
\hline \multirow[b]{2}{*}{ age $x$} & \multicolumn{4}{|c|}{ POOR 1980} & \multicolumn{4}{|c|}{ MIDDLE 1980} \\
\hline & $I_{(x)}$ & ${ }_{n} d_{x}$ & ${ }_{n} \mathbf{L}_{x}$ & $\mathbf{T}_{\mathrm{x}}$ & $I_{(x)}$ & ${ }_{n} d_{x}$ & ${ }_{n} L_{x}$ & $\mathbf{T}_{\mathrm{x}}$ \\
\hline 0 & 100,000 & 13,334 & 438,431 & $5,951,166$ & 100,000 & 9,321 & 457,596 & $6,238,975$ \\
\hline 5 & 86,666 & 463 & 432,171 & $5,512,735$ & 90,679 & 400 & 452,396 & $5,781,379$ \\
\hline 10 & 86,202 & 400 & 430,011 & $5,080,564$ & 90,279 & 348 & 450,526 & $5,328,984$ \\
\hline 15 & 85,802 & 721 & 427,207 & $4,650,553$ & 89,931 & 633 & 448,073 & $4,878,457$ \\
\hline 20 & 85,081 & 1,068 & 422,734 & $4,223,347$ & 89,298 & 952 & 444,109 & $4,430,385$ \\
\hline 25 & 84,013 & 1,272 & 416,885 & $3,800,612$ & 88,346 & 1,156 & 438,837 & $3,986,276$ \\
\hline 30 & 82,741 & 1,549 & 409,831 & $3,383,728$ & 87,189 & 1,439 & 432,349 & $3,547,438$ \\
\hline 35 & 81,192 & 2,004 & 400,948 & $2,973,896$ & 85,750 & 1,908 & 423,982 & $3,115,089$ \\
\hline 40 & 79,188 & 2,472 & 389,758 & $2,572,948$ & 83,842 & 2,422 & 413,157 & $2,691,107$ \\
\hline 45 & 76,716 & 3,185 & 375,617 & $2,183,190$ & 81,421 & 3,221 & 399,051 & $2,277,950$ \\
\hline 50 & 73,531 & 3,876 & 357,964 & $1,807,573$ & 78,200 & 4,058 & 380,854 & $1,878,899$ \\
\hline 55 & 69,655 & 4,918 & 335,979 & $1,449,609$ & 74,142 & 5,334 & 357,372 & $1,498,046$ \\
\hline 60 & 64,737 & 6,196 & 308,196 & $1,113,630$ & 68,807 & 6,960 & 326,635 & $1,140,674$ \\
\hline 65 & 58,541 & 7,525 & 273,895 & 805,434 & 61,847 & 8,706 & 287,469 & 814,038 \\
\hline 70 & 51,017 & 10,431 & 229,005 & 531,538 & 53,141 & 12,270 & 235,029 & 526,569 \\
\hline 75 & 40,585 & 11,699 & 173,680 & 302,533 & 40,871 & 13,570 & 170,429 & 291,540 \\
\hline \multirow[t]{3}{*}{80} & 28,886 & 28,886 & 128,853 & 128,853 & 27,301 & 27,301 & 121,111 & 121,111 \\
\hline & \multicolumn{4}{|c|}{ POOR 1991} & \multicolumn{4}{|c|}{ MIDDLE 1991} \\
\hline & $I_{(x)}$ & ${ }_{n} d_{x}$ & ${ }_{n} L_{x}$ & $\mathbf{T}_{\mathrm{x}}$ & $I_{(x)}$ & ${ }_{n} d_{x}$ & ${ }_{n} L_{x}$ & $\mathbf{T}_{\mathrm{x}}$ \\
\hline 0 & 100,000 & 9,447 & 455,557 & $6,233,143$ & 100,000 & 5,170 & 475,986 & $6,652,898$ \\
\hline 5 & 90,553 & 350 & 451,888 & $5,777,586$ & 94,830 & 244 & 473,542 & $6,176,912$ \\
\hline 10 & 90,202 & 349 & 450,140 & $5,325,698$ & 94,587 & 245 & 472,320 & $5,703,369$ \\
\hline 15 & 89,853 & 801 & 447,263 & $4,875,558$ & 94,341 & 573 & 470,275 & $5,231,049$ \\
\hline 20 & 89,052 & 1,190 & 442,284 & $4,428,295$ & 93,769 & 875 & 466,657 & $4,760,774$ \\
\hline 25 & 87,862 & 1,388 & 435,839 & $3,986,011$ & 92,894 & 1,054 & 461,834 & $4,294,117$ \\
\hline 30 & 86,474 & 1,626 & 428,305 & $3,550,171$ & 91,839 & 1,281 & 455,995 & $3,832,284$ \\
\hline 35 & 84,848 & 1,952 & 419,361 & $3,121,866$ & 90,559 & 1,599 & 448,797 & $3,376,288$ \\
\hline 40 & 82,896 & 2,454 & 408,347 & $2,702,504$ & 88,960 & 2,100 & 439,552 & $2,927,491$ \\
\hline 45 & 80,442 & 3,180 & 394,261 & $2,294,157$ & 86,861 & 2,860 & 427,153 & $2,487,940$ \\
\hline 50 & 77,262 & 4,139 & 375,962 & $1,899,896$ & 84,000 & 3,940 & 410,153 & $2,060,787$ \\
\hline 55 & 73,123 & 5,185 & 352,650 & $1,523,934$ & 80,061 & 5,250 & 387,179 & $1,650,634$ \\
\hline 60 & 67,937 & 6,450 & 323,562 & $1,171,284$ & 74,811 & 6,956 & 356,665 & $1,263,455$ \\
\hline 65 & 61,487 & 8,112 & 287,158 & 847,723 & 67,855 & 9,293 & 316,043 & 906,790 \\
\hline 70 & 53,376 & 10,422 & 240,823 & 560,565 & 58,562 & 12,542 & 261,455 & 590,747 \\
\hline 75 & 42,954 & 12,543 & 183,410 & 319,742 & 46,020 & 15,356 & 191,712 & 329,292 \\
\hline 80 & 30,411 & 30,411 & 136,331 & 136,331 & 30,664 & 30,664 & 137,580 & 137,580 \\
\hline
\end{tabular}


(continuação)

\begin{tabular}{|c|c|c|c|c|c|c|c|c|}
\hline \multicolumn{5}{|c|}{ RICH 1980} & \multicolumn{4}{|c|}{ ALL CLASSES 1980} \\
\hline & $I_{(x)}$ & $n^{d} x$ & ${ }_{n} \mathrm{~L} x$ & $\mathbf{T}_{\mathrm{x}}$ & $I_{(x)}$ & ${ }_{n} d_{x}$ & ${ }^{2} \mathbf{L} \times$ & $T_{x}$ \\
\hline 0 & 100,000 & 7,157 & 466,318 & $7,312,358$ & 100,000 & 11,301 & 447,927 & $6,207,821$ \\
\hline 5 & 92,843 & 179 & 463,766 & $6,846,039$ & 88,699 & 406 & 442,477 & $5,759,894$ \\
\hline 10 & 92,664 & 154 & 462,934 & $6,382,274$ & 88,292 & 352 & 440,582 & $5,317,417$ \\
\hline 15 & 92,510 & 275 & 461,861 & $5,919,340$ & 87,941 & 635 & 438,116 & $4,876,835$ \\
\hline 20 & 92,235 & 404 & 460,163 & $5,457,479$ & 87,306 & 943 & 434,171 & $4,438,719$ \\
\hline 25 & 91,831 & 476 & 457,963 & $4,997,315$ & 86,363 & 1,129 & 428,990 & $4,004,547$ \\
\hline 30 & 91,354 & 575 & 455,336 & $4,539,352$ & 85,234 & 1,383 & 422,711 & $3,575,557$ \\
\hline 35 & 90,780 & 737 & 452,057 & $4,084,016$ & 83,851 & 1,801 & 414,752 & $3,152,846$ \\
\hline 40 & 90,043 & 904 & 447,954 & $3,631,959$ & 82,050 & 2,241 & 404,647 & $2,738,094$ \\
\hline 45 & 89,139 & 1,164 & 442,785 & $3,184,005$ & 79,809 & 2,918 & 391,750 & $2,333,447$ \\
\hline 50 & 87,975 & 1,428 & 436,306 & $2,741,220$ & 76,891 & 3,599 & 375,459 & $1,941,697$ \\
\hline 55 & 86,547 & 1,851 & 428,109 & $2,304,914$ & 73,292 & 4,639 & 354,865 & $1,566,238$ \\
\hline 60 & 84,696 & 2,435 & 417,394 & $1,876,806$ & 68,654 & 5,962 & 328,362 & $1,211,373$ \\
\hline 65 & 82,261 & 3,192 & 403,324 & $1,459,412$ & 62,691 & 7,418 & 294,911 & 883,011 \\
\hline 70 & 79,069 & 5,090 & 382,619 & $1,056,088$ & 55,273 & 10,606 & 249,851 & 588,100 \\
\hline 75 & 73,979 & 7,279 & 351,698 & 673,469 & 44,667 & 12,342 & 192,480 & 338,249 \\
\hline 80 & 66,700 & 66,700 & 321,771 & 321,771 & 32,325 & 32,325 & 145,769 & 145,769 \\
\hline \multicolumn{5}{|c|}{ RICH 1991} & \multicolumn{4}{|c|}{ ALL CLASSES 1991} \\
\hline & $I_{(x)}$ & ${ }_{n} d_{x}$ & ${ }_{n} L_{x}$ & $\mathbf{T}_{\mathrm{x}}$ & $I(x)$ & ${ }_{n} d_{x}$ & ${ }_{n} L_{x}$ & $T_{x}$ \\
\hline 0 & 100,000 & 4,343 & 479,195 & $7,715,879$ & 100,000 & 7,326 & 465,627 & $6,533,354$ \\
\hline 5 & 95,657 & 103 & 478,026 & $7,236,684$ & 92,674 & 287 & 462,655 & $6,067,727$ \\
\hline 10 & 95,554 & 102 & 477,515 & $6,758,658$ & 92,387 & 287 & 461,221 & $5,605,072$ \\
\hline 15 & 95,452 & 230 & 476,687 & $6,281,143$ & 92,101 & 661 & 458,853 & $5,143,851$ \\
\hline 20 & 95,222 & 333 & 475,279 & $5,804,457$ & 91,440 & 989 & 454,729 & $4,684,999$ \\
\hline 25 & 94,889 & 379 & 473,499 & $5,329,177$ & 90,451 & 1,163 & 449,349 & $4,230,270$ \\
\hline 30 & 94,510 & 433 & 471,469 & $4,855,678$ & 89,288 & 1,377 & 442,997 & $3,780,922$ \\
\hline 35 & 94,077 & 509 & 469,114 & $4,384,209$ & 87,911 & 1,672 & 435,373 & $3,337,924$ \\
\hline 40 & 93,568 & 627 & 466,274 & $3,915,096$ & 86,238 & 2,132 & 425,861 & $2,902,552$ \\
\hline 45 & 92,941 & 801 & 462,702 & $3,448,822$ & 84,106 & 2,810 & 413,506 & $2,476,691$ \\
\hline 50 & 92,140 & 1,036 & 458,108 & $2,986,120$ & 81,296 & 3,734 & 397,147 & $2,063,185$ \\
\hline 55 & 91,103 & 1,311 & 452,239 & $2,528,011$ & 77,563 & 4,795 & 375,824 & $1,666,038$ \\
\hline 60 & 89,792 & 1,689 & 444,738 & $2,075,773$ & 72,767 & 6,142 & 348,480 & $1,290,214$ \\
\hline 65 & 88,103 & 2,289 & 434,794 & $1,631,035$ & 66,625 & 7,997 & 313,133 & 941,734 \\
\hline 70 & 85,814 & 3,393 & 420,591 & $1,196,241$ & 58,628 & 10,702 & 266,386 & 628,601 \\
\hline 75 & 82,422 & 5,315 & 398,822 & 775,650 & 47,926 & 13,480 & 205,930 & 362,215 \\
\hline 80 & 77,107 & 77,107 & 376,828 & 376,828 & 34,446 & 34,446 & 156,285 & 156,285 \\
\hline
\end{tabular}


(continuação)

\begin{tabular}{|c|c|c|c|c|c|c|c|c|}
\hline \multirow[b]{2}{*}{ age $x$} & \multicolumn{4}{|c|}{ POOR 2000} & \multicolumn{4}{|c|}{ MIDDLE 2000} \\
\hline & $I_{(x)}$ & ${ }^{d}{ }^{x}$ & ${ }^{n}{ }^{x} x$ & $T_{x}$ & $I_{(x)}$ & ${ }_{n} d_{x}$ & ${ }_{n} L_{x}$ & $T_{x}$ \\
\hline 0 & 100,000 & 5,687 & 474,138 & $6,543,130$ & 100,000 & 3,088 & 486,254 & $7,100,844$ \\
\hline 5 & 94,313 & 276 & 470,874 & $6,068,992$ & 96,912 & 163 & 484,150 & $6,614,590$ \\
\hline 10 & 94,037 & 307 & 469,416 & $5,598,118$ & 96,748 & 183 & 483,285 & $6,130,440$ \\
\hline 15 & 93,730 & 858 & 466,503 & $5,128,702$ & 96,565 & 516 & 481,537 & $5,647,156$ \\
\hline 20 & 92,872 & 1,280 & 461,158 & $4,662,199$ & 96,049 & 785 & 478,284 & $5,165,619$ \\
\hline 25 & 91,591 & 1,433 & 454,374 & $4,201,041$ & 95,264 & 898 & 474,076 & $4,687,335$ \\
\hline 30 & 90,158 & 1,642 & 446,686 & $3,746,667$ & 94,366 & 1,054 & 469,196 & $4,213,259$ \\
\hline 35 & 88,516 & 1,954 & 437,695 & $3,299,982$ & 93,312 & 1,287 & 463,345 & $3,744,063$ \\
\hline 40 & 86,562 & 2,515 & 426,521 & $2,862,287$ & 92,026 & 1,707 & 455,860 & $3,280,718$ \\
\hline 45 & 84,046 & 3,265 & 412,069 & $2,435,766$ & 90,318 & 2,300 & 445,843 & $2,824,858$ \\
\hline 50 & 80,781 & 4,135 & 393,567 & $2,023,697$ & 88,019 & 3,046 & 432,479 & $2,379,015$ \\
\hline 55 & 76,646 & 5,377 & 369,787 & $1,630,130$ & 84,973 & 4,184 & 414,404 & $1,946,536$ \\
\hline 60 & 71,269 & 6,750 & 339,469 & $1,260,343$ & 80,789 & 5,616 & 389,904 & $1,532,132$ \\
\hline 65 & 64,519 & 8,252 & 301,966 & 920,874 & 75,173 & 7,432 & 357,285 & $1,142,228$ \\
\hline 70 & 56,267 & 9,997 & 256,343 & 618,908 & 67,741 & 9,878 & 314,011 & 784,943 \\
\hline 75 & 46,270 & 11,223 & 203,291 & 362,565 & 57,863 & 12,286 & 258,601 & 470,932 \\
\hline 80 & 35,047 & 35,047 & 159,274 & 159,274 & 45,577 & 45,577 & 212,331 & 212,331 \\
\hline
\end{tabular}

\begin{tabular}{|c|c|c|c|c|c|c|c|c|}
\hline \multirow[b]{2}{*}{ age $x$} & \multicolumn{4}{|c|}{ RICH 2000} & \multicolumn{4}{|c|}{ ALL CLASSES 2000} \\
\hline & $I_{(x)}$ & ${ }_{n} d_{x}$ & ${ }_{n} L \times$ & $\mathbf{T}_{\mathrm{x}}$ & $I_{(x)}$ & ${ }_{n} d_{x}$ & ${ }_{n} L_{x}$ & $T_{x}$ \\
\hline 0 & 100,000 & 1,642 & 492,423 & $7,970,679$ & 100,000 & 4,236 & 480,768 & $6,876,296$ \\
\hline 5 & 98,358 & 65 & 491,628 & $7,478,256$ & 95,764 & 210 & 478,295 & $6,395,528$ \\
\hline 10 & 98,293 & 72 & 491,285 & $6,986,628$ & 95,554 & 235 & 477,183 & $5,917,233$ \\
\hline 15 & 98,221 & 199 & 490,607 & $6,495,343$ & 95,319 & 658 & 474,952 & $5,440,050$ \\
\hline 20 & 98,022 & 292 & 489,378 & $6,004,736$ & 94,662 & 988 & 470,838 & $4,965,098$ \\
\hline 25 & 97,729 & 323 & 487,839 & $5,515,358$ & 93,674 & 1,116 & 465,579 & $4,494,260$ \\
\hline 30 & 97,406 & 366 & 486,117 & $5,027,519$ & 92,558 & 1,290 & 459,566 & $4,028,681$ \\
\hline 35 & 97,040 & 434 & 484,117 & $4,541,402$ & 91,268 & 1,552 & 452,462 & $3,569,114$ \\
\hline 40 & 96,606 & 559 & 481,636 & $4,057,286$ & 89,717 & 2,024 & 443,523 & $3,116,652$ \\
\hline 45 & 96,048 & 733 & 478,408 & $3,575,650$ & 87,693 & 2,672 & 431,784 & $2,673,129$ \\
\hline 50 & 95,315 & 950 & 474,201 & $3,097,242$ & 85,021 & 3,457 & 416,463 & $2,241,346$ \\
\hline 55 & 94,365 & 1,292 & 468,595 & $2,623,042$ & 81,564 & 4,619 & 396,273 & $1,824,883$ \\
\hline 60 & 93,073 & 1,751 & 460,987 & $2,154,447$ & 76,945 & 6,004 & 369,716 & $1,428,610$ \\
\hline 65 & 91,322 & 2,414 & 450,576 & $1,693,460$ & 70,941 & 7,663 & 335,550 & $1,058,895$ \\
\hline 70 & 88,908 & 3,519 & 435,745 & $1,242,884$ & 63,279 & 9,787 & 291,926 & 723,345 \\
\hline 75 & 85,390 & 5,209 & 413,926 & 807,140 & 53,492 & 11,689 & 238,237 & 431,419 \\
\hline 80 & 80,181 & 80,181 & 393,213 & 393,213 & 41,803 & 41,803 & 193,181 & 193,181 \\
\hline
\end{tabular}

Source: Self-elaboration based on the 1980, 1991 and 2000 Brazilian Census. 